\title{
PINTURA MURAL DE LA VILLA ROMANA DE BALAZOTE (ALBACETE) ${ }^{1}$
}

\author{
ALICIA FERNÁNDEZ DÍAZ \\ Universidad de Murcia
}

\begin{abstract}
Con este estudio pretendemos sacar a la luz un importante conjunto de pintura mural procedente de la villa romana de Balazote (Albacete), de la que hasta ahora se habian realizado un gran número de trabajos, incluidos los relativos a su decoración musiva, pero en los que no se habia tratado de forma más completa el tema de los revestimientos pictóricos de sus paredes. La totalidad de los fragmentos procede del área termal y su importancia radica principalmente en ser uno de los pocos ejemplos de decoración figurada con representaciones de palestra que encontramos en la península Ibérica y en el resto de las provincias romanas de Occidente.
\end{abstract}

Avec cette étude nous prétendons donner à connaître un important ensemble de peintures murales de la villa romaine de Balazote (Albacete), de laquelle jusqu'à présent on avait effectué un grand nombre de travaux, et compris ceux relatifs à sa décoration musiva, mais dans lesquels on n'avait pas traité de manière plus complète le sujet des revêtements picturaux de ses parois. La totalité des fragments vient du secteur thermal et son importance est principalement d'être un des rares exemples de décoration figurée avec des représentations de palestra que nous trouvons dans la péninsule ibérique et dans le reste des provinces romaines d'occident.

El área excavada de Balazote se localiza en el borde occidental de los Llanos de Albacete, una amplia zona endorreica con pequeñas lagunas, pozos y cursos de agua que desaparecen bajo el suelo. La presencia del río Balazote al que confluyen los anteriores cursos de agua, da lugar a una vega con limos y arenas que nunca llega a alcanzar los $1000 \mathrm{~m}$ de altitud, cota usual por tanto en los asentamientos romanos de la zona manchega en la que se encuadra la provincia albaceteña -únicamente el sector noroeste alcanza mayores altitudes-. Todas estas características físicas existencia de un río o fuente provisoria de agua y de ricas tierras de cultivo-, facilitan la elección de este lugar como asentamiento pues permiten una economía agrícola importante que, al igual que sucede en las villae de Portmán (Fernández, 1999) y La Quintilla (Ramallo et alii, 2005) para el caso de Murcia, entre otras, se adecuan a los consejos dados por algunos tratadistas como Varrón y Columela, entre otros. Esta zona se encuentra además muy próxima al tramo de calzada en el que convergen el Camino de Aníbal con la vía 31 del Itinerario de Antonino $(446,11$ y 447,1$)$, entre Parietinis y Libisosa ( $C I L$ XI, 3.281 a 3.284).

Del conjunto de la villa, situado en el Camino Viejo de Las Sepulturas, se tenían noticias muy puntuales desde 1952 (recogidas en $N A H ., 1$ ), aunque no fue hasta los años 70 el momento en que fue excavada por primera vez por S. de los Santos ${ }^{2}$. Los resultados de estas excavaciones fueron publicados a modo de breves artículos que apenas hacen referencia a las mismas, sino más bien a los espléndidos pavimentos musivos que aparecieron en las diferentes estancias descubiertas (Santos, 1977 a y 1977 b). Tras estos primeros trabajos, han sido algunos los estudios que se han publicado sobre la villa, más concretamente, so-

\footnotetext{
${ }^{1}$ Mi más sincero agradecimiento a R. Sanz Gamo, Directora del Museo provincial de Albacete, por haber puesto a mi disposición todo el material pictórico de las excavaciones así como por permitirme su estudio. De la misma manera, agradezco al profesor Lorenzo Abad el que me pusiera sobre la pista del mismo.

2 La zona no volvíó a ser excavada hasta 1986 cuando se puso en relación el área residencial del yacimiento con la pars rustica. Véase para ello Sanz Gamo (1995, 339-356).
} 


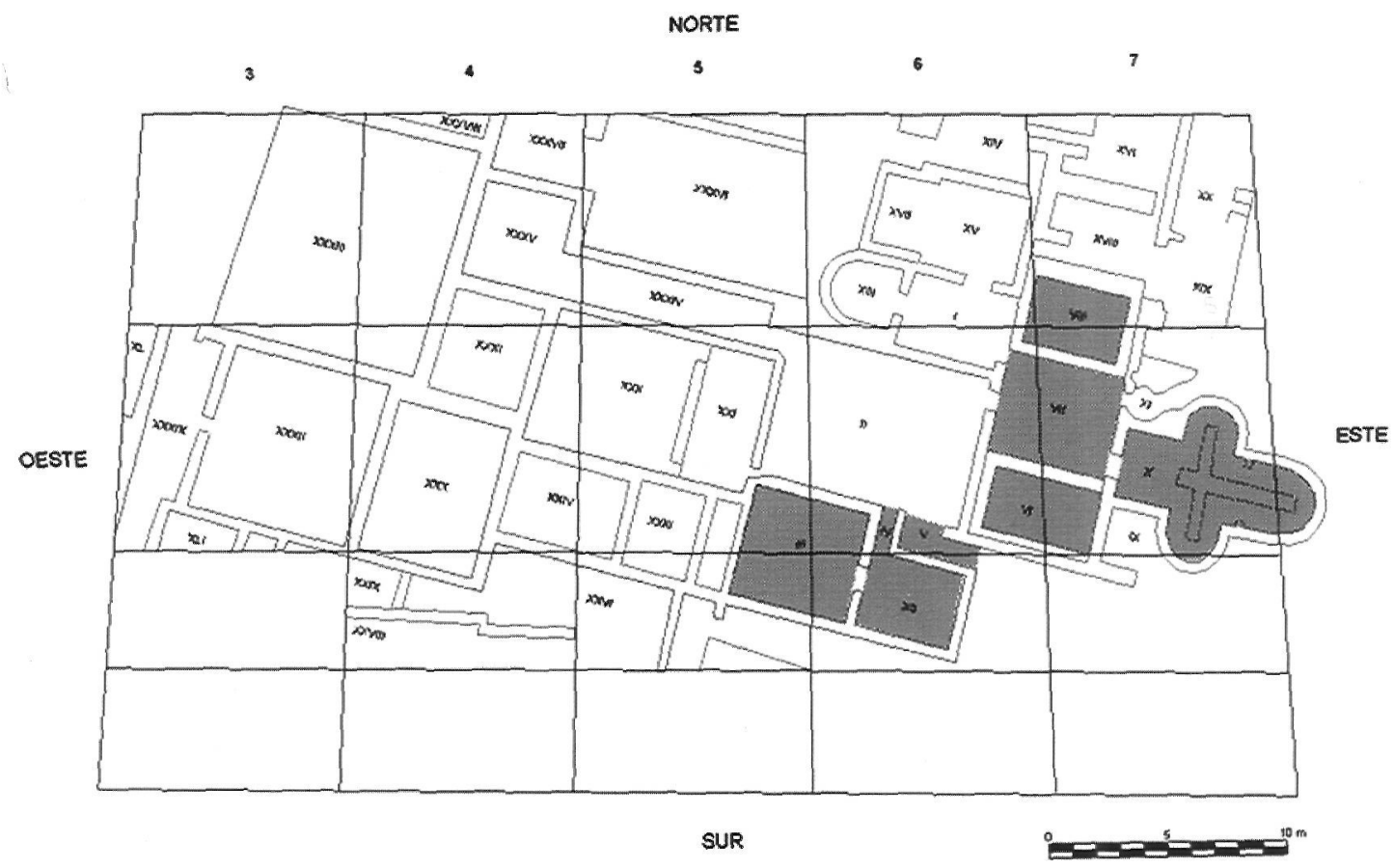

Figura 1: Planimetría del complejo termal y localización de las pinturas (Museo Arqueológico).

bre sus mosaicos (Sanz, 1987c; Blázquez et alii, 1989) y especialmente sobre las termas (Sanz, 1987a; 1987b y 1989a; Garcia, 1997 y 2001) o el asentamiento rural en el que ésta se inserta (Sanz, 1989b y 1995).

En cuanto a la cronología de la villa, hay un gran número de interrogantes debido esencialmente a la falta de nuevas excavaciones y de diferentes versiones de su única planimetría, pero podemos decir que, en líneas generales, ésta se desarrolla en varias fases. Al parecer la villa se asentó antes de finales del siglo II d.C. sobre un hábitat ibérico precedente, momento en el que se datan una serie de esculturas vinculadas generalmente a establecimientos de tipo termal -posiblemente el primero de la villa-y que serían posteriormente reutilizadas (Noguera, 1994, 45-75, 175-182, 228-229, láms. 2-20). No obstante, algunos autores sitúan la primera fase en el siglo I d.C. (Gorges, 1979, 179), siendo la segunda su época de máximo esplendor entre los siglos II-III d.C. (Sanz, 1995, 344, 352 y 354; Fernández, 1982, 130). Independientemente de esa diferenciación, parece claro que a principios del siglo III d.C., se produce la construcción de la última villa y de sus instalaciones termales, sufriendo estas últimas escasas reformas durante el siglo IV d.C. La definición e interpretación de esta última fase constructiva es bastante problemática puesto que únicamente contamos con dataciones fia- bles ofrecidas por los pavimentos de mosaicos estudiados por J.M Blázquez, quien avanza una fecha que oscila entre los siglos III-IV d.C. (Blázquez et alii, 1989; Blázquez, 1993, 430). El final del establecimiento parece relacionarse con algún hecho de carácter violento entre los siglos IV y V d.C., como se constata de los enterramientos situados en la zona de La Vega (Sanz, 1989b, 244 y 1995, 352).

\section{TERMAS PRIVADAS}

Los baños de la villa de Balazote constituyen un magnífico ejemplo de gran balneum doméstico rural en la Hispania del siglo III d.C. y su gran aparato decorativo-ornamental demuestra que se inserta en una de las zonas de mayor prestigio y representación de toda ella. En un primer momento $S$. de los Santos contabilizó como estructuras arqueológicas pertenecientes al complejo termal, un total de 41 espacios arquitectónicos diferenciados pero a la vez yuxtapuestos en la totalidad del asentamiento (Sanz, 1989b, 243-349 y 1995, 341) (Fig. 1) ${ }^{3}$. Sin embargo, debido a la falta de datos de anteriores excavaciones, únicamente se

\footnotetext{
3 Véase García (2001, 33-34 y n. 15): “De los 41 espacios tan sólo 15 ocuparon la zona termal, espacios que podemos identificar con 8 estancias".
} 
puede conocer la articulación racionalizada del sector oriental compuesto por habitaciones calefactadas y estancias anejas. De esta manera, el complejo estuvo formado en realidad tan sólo por ocho estancias, sin contar con las zonas de servicio, del total de ambientes identificados por $\mathrm{S}$. de los Santos y que, de forma generalizada, habían sido tradicionalmente vinculados en su totalidad al balneum.

El complejo ocupa el extremo noreste de la superficie conocida de la villa, formando un conjunto arquitectónico unitario con el resto de la misma, con una orientación NE-SO. El sector que nos interesa se sitúa en la parte occidental del conjunto arquitectónico y corresponde a las habitaciones más lujosas, quizá la zona noble excavada por S. de los Santos (Santos, 1977a, 249-254 y 1977b, 367-370, láms. I-II), de la que conservamos restos de pavimentos, de mármoles decorativos -alguno de ellos con inscripción (Abascal, 1990, 34; Sanz, 1995, 344)-, fragmentos escultóricos recogidos por J.M Noguera Celdrán en su tesis doctoral y, por último, lo que aquí más nos interesa, restos de enlucido decorado con motivos geométricos, vegetales $\mathrm{y}$, sobre todo, escenas de palestra.

\section{PINTURA MURAL}

No conservamos restos pictóricos de todas las estancias termales, pero para realizar una breve sintesis de lo que existe antes de comenzar con el estudio propiamente dicho, seguiremos el recorrido propio de éstas centrándonos concretamente en el sector occidental de las mismas. El acceso se haría por la sala II o apodyterium, de donde proceden algunos fragmentos aislados hallados en el derrumbe de su ángulo NO (Sanz, 1989b, 244). Desde esta estancia se accede a otras tres situadas al este -VI, VII y VIII- y que pueden ser consideradas como el frigidarium o a otra sala situada al sur -XII-, pequeña y rectangular, cuya funcionalidad concreta desconocemos aunque dada su ubicación junto a la zona fría de las termas podría actuar como unctorium, un tipo de estancias termales relacionadas con la toma de aceites pero difícilmente identificables desde el punto de vista arquitectónico, ya que pueden adoptar cualquier forma y su ubicación dentro del recorrido termal varía (Nielsen, 1990, $\mathrm{I}, 161)^{4}$. Esta funcionalidad estaría confirmada por la decoración parietal hallada en el derrumbe de la misma, que presenta una decoración figurada con escenas de personajes masculi- nos que se untan el cuerpo con aceite. Esta estancia da paso a otra -III-parcialmente pavimentada con ladrillos sesquipedales que apoyan sobre un pavimento anterior posiblemente constituido por un mosaico (Sanz, 1989b, 244) y enlucida con pinturas de motivos geométricos y antropomorfos. Su funcionalidad posiblemente sería la misma que la anterior (García, 2001, 34). En último lugar, conservamos algunos fragmentos pictóricos con imitación de un tipo de mármol moteado procedentes de la estancia $X$, una sala trilobulada sobre hypocaustum en la que tradicionalmente algunos autores han querido ver un caldarium o laconicum (Santos, 1977b, 369), otros una de esas reformas puntuales del siglo IV d.C., que hemos mencionado anteriormente (Fernández, 1982,130) y, más recientemente se ha denominado como la sudatio de las instalaciones termales (García, 2001, fig. en p. 34).

Actualmente, todos los fragmentos recuperados se encuentran en el Museo Provincial de Albacete, repartidos entre sus vitrinas y sus fondos. Lo que a continuación presentamos es el avance de su estudio, un trabajo que tenemos en marcha a falta de los resultados que se obtengan tras la reciente restauración que se está llevando a cabo ${ }^{5}$. Si atendemos al tema pictórico, de entre todos los fragmentos, los más destacados corresponden a las pinturas que representan alguna actividad relativa o relacionada con los baños y con los ejercicios físicos propios de una zona próxima que funciona como palestra, aunque incluimos también otros fragmentos singulares que completan la composición.

\section{1. Análisis descriptivo y estilístico}

A continuación, mostramos el estudio de la decoración pictórica de las distintas salas termales siguiendo el orden que hemos escogido anteriormente y, dentro de éste, el orden de disposición que ocupa en la pared, es decir, en primer lugar, aquellos fragmentos que se suelen representar en la zona inferior $y$, en segundo lugar, aquellos otros que se representan en la zona media de ésta.

\footnotetext{
${ }^{4}$ Según este autor, los unctoria suelen ocupar lugares próximos a los frigidaria y apodyteria puesto que el bañista realizaría esta acción tras la toma del baño frío que ponía punto final a su circuito termal

5 Agradezco a $D^{a}$. Ma. Fernanda Pascual Martínez, restauradora que lleva a cabo dichos trabajos, la muestra de nuevos fragmentos que han aparecido en los fondos del Museo Provincial de Albacete.
} 


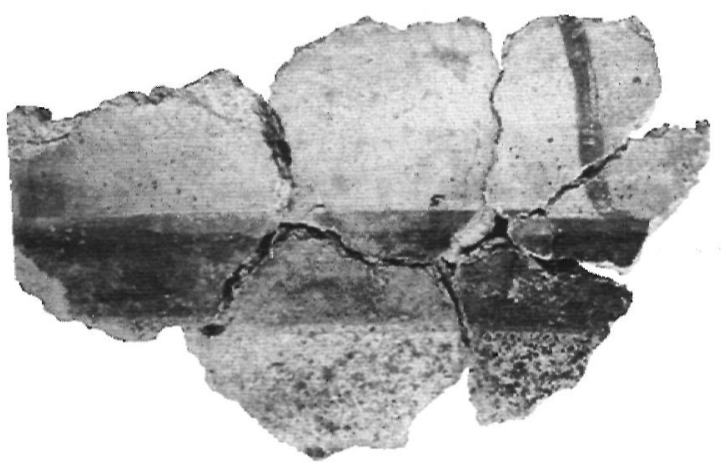

Figura 2: Imitación de un rodapié y zócalo de mármol cipollino de la pared sur de la estancia V (Foto: A. Fernández).

\section{1. 1. Habitaciones III, V y XII}

II. 1. 1. 1. Zona inferior con imitación de már$\mathrm{mol}$

La mayor parte de los fragmentos que podemos encuadrar en este conjunto provienen de la habitación $V$ de las termas y de algunas cajas de procedencia desconocida, pero que por su enorme semejanza con los anteriores, podríamos considerarlos de la misma estancia.

De la habitación $V y$, más concretamente de la cuadrícula E6, conservamos un total de dieciocho fragmentos informes de pintura mural $^{6}$. Su esquema consiste en una banda amarilla de la que desconocemos su anchura pero que como mínimo tiene $1,5 \mathrm{~cm}$, una banda blanca de $2,5 \mathrm{~cm}$ de anchura, otra banda amarilla de $3,6 \mathrm{~cm}$ de anchura y todo ello decorado con pequeñísimas motas negras y filetes negros y verdes que, de manera sinuosa, atraviesan transversalmente dichas bandas; a continuación se representa una nueva banda negra de $5 \mathrm{~cm}$ de anchura, un campo blanco grisáceo con moteado negro y $6,5 \mathrm{~cm}$ de anchura mínima conservada y un campo amarillo con imitación de vetas rojas. En líneas generales podría tratarse de la representación del rodapié y zócalo de la pared sur de dicha estancia (Fig. 2).

A esta misma habitación pertenece otro fragmento con imitación de mármol "giallo antico" o numidicum cuya capa superficial está parcialmente tapada mediante una lechada de $\mathrm{Cal}^{7}$ (Fig. 3). Desconocemos si se trata de una fase anterior o corresponde a una localización cercana de un arranque de vano o puerta de acceso a dicha estancia, pero lo que sí es seguro es que corresponde al registro inferior o zócalo y podría ser la parte superior de los frag-

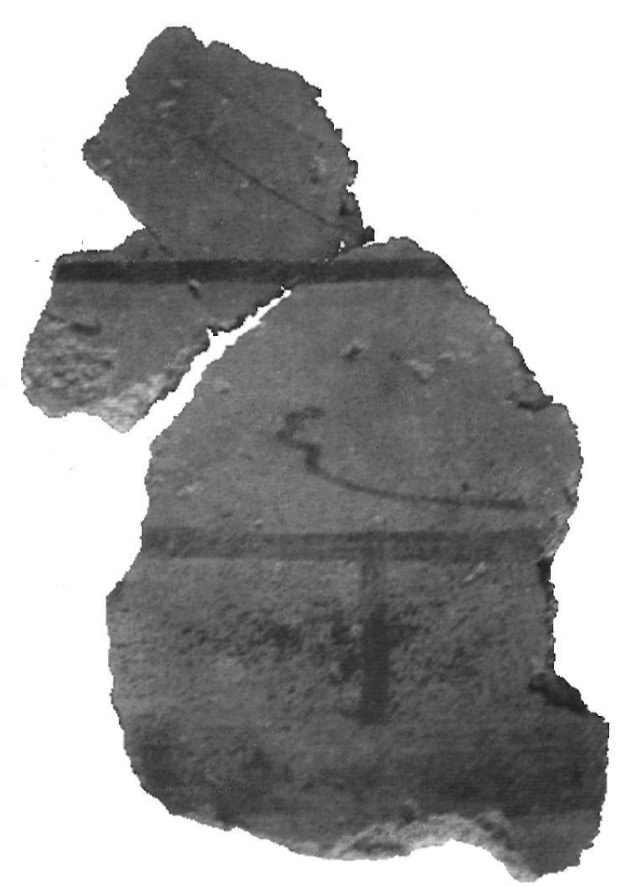

Figura 3: Imitación de mármol numidicum o "giallo antico" (Foto: A. Fernández).

mentos anteriormente descritos. Un dato curioso al respecto resulta el hallazgo en la campaña de 1974 de un grupo de seis fragmentos informes de pintura mural con el mismo tipo de imitación, incluida la banda de encuadramiento o lastra marmórea. Aunque desconocemos su localización exacta en la planta general de las termas, posiblemente estaría ubicado en la zona inferior o zócalo de la pared ${ }^{8}$. Esto nos lleva a pensar que, independientemente de la estancia a la que pertenezca, el programa decorativo de las termas es homogéneo en la mayor parte de sus salas.

Asimismo, conservamos un total de cincuenta fragmentos informes de pintura mural correspondientes a la imitación de moteado

\footnotetext{
${ }^{6}$ Ficha técnica: Caja 49. 1/2. Cuadrícula E6 de la habitación $V$, pero sin referencia de año. $N^{\circ}$ inventario provisional 5/9(an). Grosor: $1^{\text {a }}$ capa: $0,3 \mathrm{~cm} ; 2^{a}$ capa: $1,3 \mathrm{~cm}$ de mortero en el que no se distingue bien la composición debido a la enorme suciedad de las piezas; $3^{a}$ capa: $2-2,8 \mathrm{~cm}$ de grosor conservado con reverso en espiga.

${ }^{7}$ Ficha técnica: Caja 49. 1/2. Cuadrícula E6 de la habitación $\mathrm{V}$, sin referencia de año. $\mathrm{N}^{\circ}$ inventario provisional $5 / 10(\mathrm{a}-\mathrm{f}$ ) (45, 48-49, 59-60). Grosor: $1^{a}$ capa: $0,2 \mathrm{~cm}$ de lechada de cal; $2^{\text {a }}$ capa: $1,7 \mathrm{~cm} ; 3^{\mathrm{a}}$ capa: $0,1 \mathrm{~cm}$ de lechada de cal que tapa una decoración precedente; $4^{\mathrm{a}}$ capa: $1,1 \mathrm{~cm} ; 5^{\mathrm{a}}$ capa: $1,4 \mathrm{~cm}$ de grosor conservado sin reverso en espiga.

${ }^{8}$ Ficha técnica: Caja 5. 1/2. Campaña 1974, cuadricula 4Ea, nivel II (1059-1116). $N^{\circ}$ inventario provisional y Grosor: $1^{a}$ capa: $0,1 \mathrm{~cm} ; 2^{\mathrm{a}}$ capa: $1,1 \mathrm{~cm} ; 3^{\mathrm{a}}$ capa: $1,1-1,2 \mathrm{~cm} ; 4^{\mathrm{a}}$ capa: $0,9 \mathrm{~cm} ; 5^{a}$ capa: $0,7-0,8 \mathrm{~cm}$ de mortero blanco sin reverso conocido.
} 


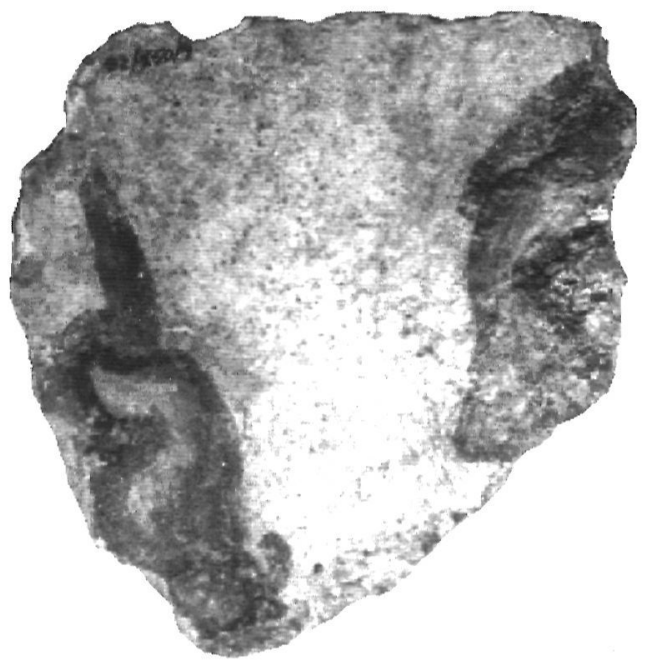

Figura 4: Representación de una cabeza de perfil y una mano con el dedo índice elevado, tal vez el árbitro de los ejercicios (vitrina del Museo, foto: A. Fernández).

negro sobre fondo blanco o grisáceo, sin localización exacta ${ }^{9}$. Este moteado parece estar dividido en pequeñas lastras o casetones, puesto que conservamos las esquinas en forma de "T" invertida de unas bandas negras de 1-1,2 $\mathrm{cm}$ de anchura, esquema muy semejante al que aparece en el zócalo de la habitación 4 de la domus de G. Iulius Silvanus en Segobriga (Cebrián y Fernández, 2004, 136-147). A su vez, contamos con imitación de mármol "cipollino" y a $8,8 \mathrm{~cm}$ de distancia una nueva banda negra que sirve de encuadramiento interior de las crustae del zócalo. La mayoría de los fragmentos minúsculos corresponden a un diminuto moteado negro sobre fondo blanco y pertenecerían a la última fase pictórica del zócalo de una pared, si tenemos en consideración que en su última capa de mortero aparecen las improntas en positivo del piqueteado de la fase precedente.

Ambos tipos de moteado e imitación de mármol son enormemente representados en toda la pintura mural romana desde los siglos II-I a.C., hasta época bajoimperial, de manera que es difícil encuadrar cronológicamente; no obstante, gracias a la aparición de cerámica terra sigillata africana clara $D$ asociada a todos ellos, podemos circunscribir estas pinturas a la fase de esplendor de la villa de Balazote contemporánea a la de los mosaicos, siglos III-IV d.C.), probablemente.

\section{1. 1. 2. Zona media o friso con escena de palestra}

II. 1. 1. 2. 1. Personajes figurados (Fernández, 2000, nº cat: 6245-6254, láms. 220-224)

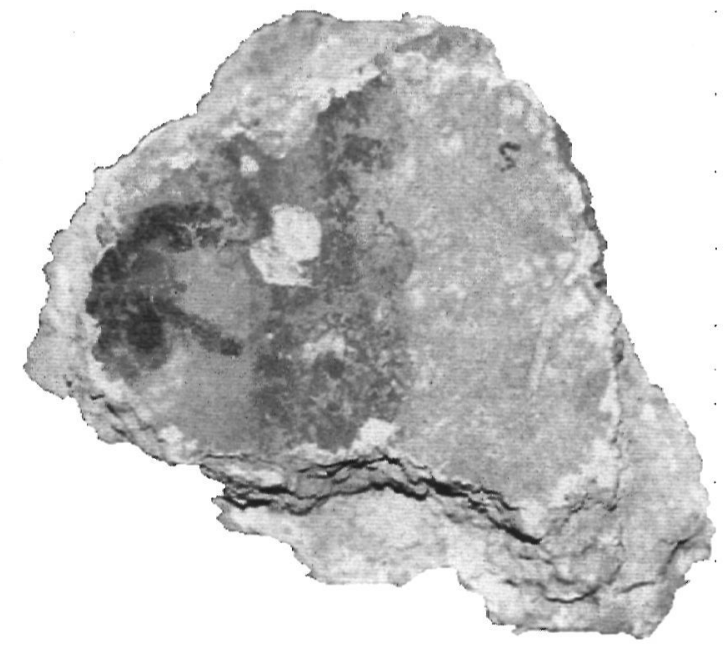

Figura 5: Fragmento con la representación de parte de una cabeza de frente (Foto: A. Fernández).

Grupo A: Alrededor de diez fragmentos informes y de medianas dimensiones representan a distintos personajes masculinos -al menos cuatro- que parecen realizar alguna actividad relacionada con los baños o con el deporte y que podrían ubicarse en un friso situado en la zona media de una de las paredes de la estancia XII ${ }^{10}$.

La primera pieza de este grupo muestra parte del rostro -ojo y nariz- y del cabello lacio de un personaje de perfil que mira hacia la derecha. Frente a él, aparece representada su mano derecha, alzada con el puño cerrado a excepción del dedo índice que sobresale y levanta hacia arriba. Los colores usados para crear el tono de la carne son diversos matices de color rojo, más o menos diluidos y todo ello sobre un fondo de color blanco (Fig. 4).

Otros dos fragmentos representan el rostro de un nuevo personaje de frente que conserva el ojo derecho, nariz y boca. La forma de realizar estos detalles del rostro, entre los que destacan unas cejas muy pobladas, la disposición del cabello, así como los colores con los que se representan, son los mismos que en la figura anterior (Fig. 5).

\footnotetext{
${ }^{9}$ Ficha técnica: Caja 49. 3/2. Sin referencia de ningún tipo. $\mathrm{N}^{\circ}$ inventario provisional $11\left(\mathrm{~b}-\mathrm{e}^{\prime}\right)$. De todos esos fragmentos, tres de ellos pegan, concretamente el equivalente a 329 , y 348-350. Grosor: $1^{\mathrm{a}}$ capa: $0,1 \mathrm{~cm} ; 2^{\mathrm{a}}$ capa: $0,9 \mathrm{~cm} 3^{\mathrm{a}}$ capa: $1,8-2,5 \mathrm{~cm}$ de grosor conservado con reverso plano y las improntas en positivo del piqueteado de una fase pictórica precedente.

${ }^{10}$ En el artículo de Sanz Gamo de 1999, Jumilla, estas piezas aparecen mencionadas como pertenecientes a la habitación III.
} 


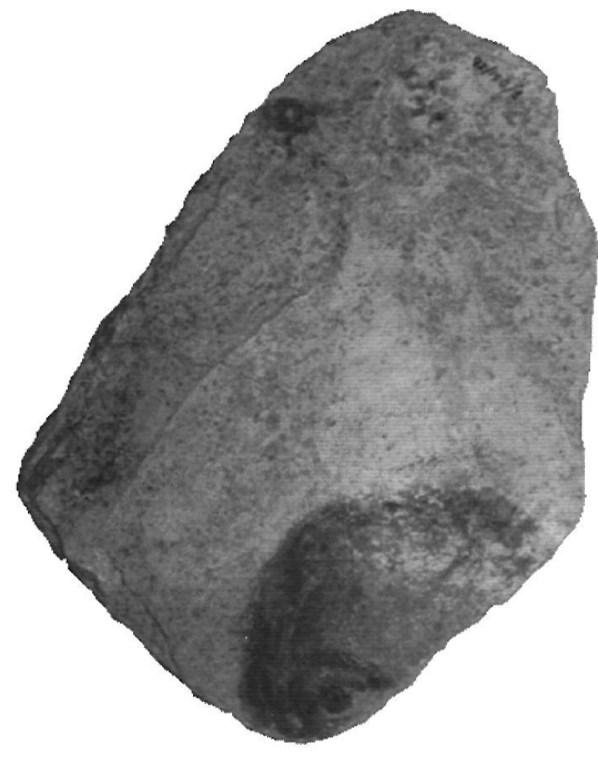

Figura 6: Representación de parte de la cabeza de un personaje de frente (vitrina del Museo, foto: A. Fernández).

Dos piezas muestran a sendos personajes distintos y también representados de frente. De uno de ellos apenas conservamos la parte superior derecha de la cabeza, incluidos ojo y ceja, muy similares en ejecución al segundo de los personajes anteriormente descrito (Fig. 6). Asimismo, este fragmento podría unir con otro perteneciente al grupo $\mathrm{C}$, concretamente al del personaje alado como veremos más adelante. Del otro conservamos toda la parte superior, incluidos el arranque de la nariz, los dos ojos y cejas, frente y cabello, pero con una ejecución más somera. Un detalle importante de este último fragmento es la presencia, cerca del cabello y en el extremo derecho, de dos pinceladas en color verde que pueden corresponderse con unas hojas similares a las que analizaremos más adelante, deduciéndose de ello que esta escena figurada podría combinarse con elementos vegetales suspendidos en el aire.

Otros tres fragmentos representan diferentes partes del cuerpo. En los dos primeros conservamos dos pies, uno de perfil y otro, el izquierdo, de frente. El que se encuentra de perfil, se representa además sobre parte del tronco de un nuevo personaje en el que aparece la marca del ombligo. A juzgar por la altura a la que se representa este pie, el tronco del otro personaje parece estar tumbado o tendido en el suelo debido a la pérdida del combate (Fig. 7). El último de los fragmentos representa a otro personaje de perfil, pero en esta ocasión en dirección hacia la izquierda y con la pierna derecha levantada hacia ese mismo lugar. Un dato más a destacar es el hecho en sí

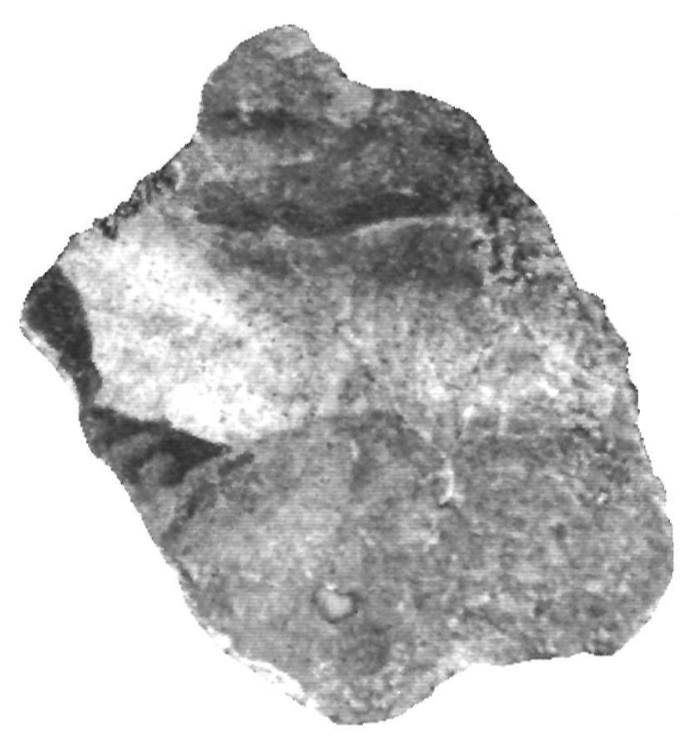

Figura 7: Representación de un pie pisando a un combatiente que ha caído al suelo (vitrina del Museo, foto: A. Fernández).

de la desnudez, pues el cuerpo de esta última figura aparece totalmente desvestido (Fig. 8).

Otras dos piezas representan la parte inferior de dos nuevos cuerpos, desde la cintura hacia los muslos. A diferencia de los anteriores personajes, éstos corresponden a posibles árbitros de los distintos combates ya que sí aparecen vestidos. Uno de ellos se presenta de frente, y el otro, posiblemente de perfil y con un manto que le cae hasta la altura de los muslos; se trata de una túnica corta a través de la cual observamos cómo se deja al descubierto la parte superior del muslo derecho. Ambas túnicas son de color blanco-grisáceo para dife-

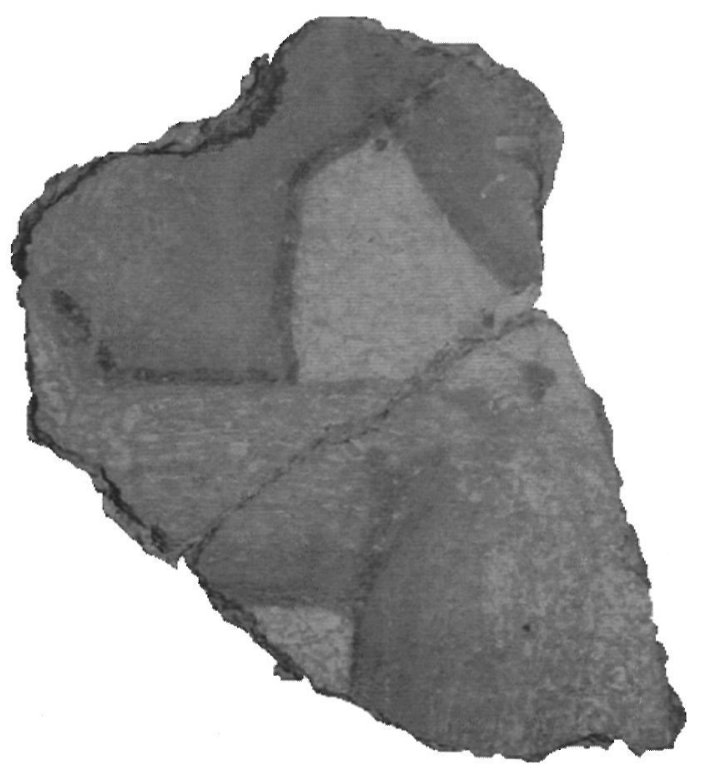

Figura 8: Representación del tronco y pierna flexionada de un personaje de perfil (vitrina del museo, foto: A. Fernández). 


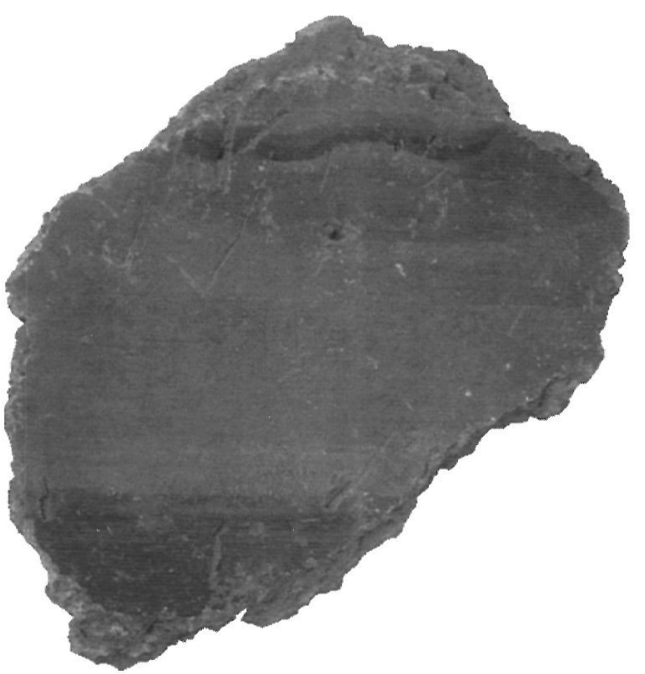

Figura 9: Fragmento con la representación de un pie de perfil sobre la arena de una palestra (Foto: A. Fernández).

renciarlas del color blanco del fondo, aunque para distinguir los pliegues también se representan con tonalidades de color ocre o verde y un reborde en púrpura muy común para este tipo de vestimenta.

En definitiva, a este primer grupo pertenecen un total de cuatro cabezas correspondientes a cuatro personajes diferentes, tres de frente y una de perfil mirando hacia la izquierda como si la representación se desarrollara únicamente en esta zona. Los fragmentos que componen estas figuras como otros que representan alguna de las partes del cuerpo, no son el único testimonio de figuras humanas en el yacimiento, pues también los encontramos en otras estancias de las termas. Algunas de ellas se muestran desnudas y otras vestidas, aunque no disponemos de ningún fragmento de túnica que pueda unirse a alguna de las cabezas de los personajes conservados para poder confirmar quiénes iban vestidos y quiénes no.

A pesar de la escasa cantidad de fragmentos de decoración pintada rescatados de esta estancia, lo que sí es seguro es que sobre fondo blanco y con un tratamiento no muy cuidado, propio también de una representación bastante tardía, los personajes aparecen representados a un tamaño bastante considerable aunque no llega a ser el real, dentro de un conjunto que puede interpretarse como una escena de palestra o relacionada con el tipo de actividades -juegos atléticos o en correspondencia con ejercicios físicos- que se realizan en las estancias termales y salas anexas. Al contrario de lo que sucede en el friso de la villa romana de Los Torrejones (Yecla, Murcia)

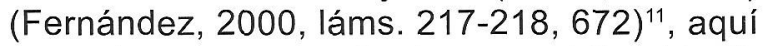
no podemos ver en ningún caso el tipo idealizado de las figuras mitológicas o heroicas de una megalografía, sino algo similar a un sainete anecdótico, a un ejercicio realizado en el descanso o tiempo de ocio de las personas que acuden a los baños. Esta podría ser la utilidad de las salas III y XII, donde los bañistas o deportistas se untarían con los aceites de las ampollas. No obstante, conservamos tres fragmentos que pegan entre sí y que corresponden a un personaje de frente y tocado con unas pequeñas alas sobre los hombros, tal vez un personaje alegórico o mitológico, posiblemente Hermes que también suele aparecer en este tipo de escenas (Reinach, 1922, fig. en p. 273).

En líneas generales, los personajes representados que encontramos de frente pueden corresponder a aquellos que practican algún tipo de ejercicio, mientras que el que se presenta de perfil y con su dedo índice levantado, puede corresponder a un árbitro que alza su mano derecha y levanta el dedo para intervenir en el buen desarrollo de una pelea con púgiles o en otra actividad dentro del contexto deportivo y sanitario que se suele difundir en este tipo de complejos.

Grupo B: Alrededor de veinte fragmentos informes y de medianas dimensiones representan nuevamente a distintos personajes masculinos -al menos cuatro- que realizan la misma actividad que en la estancia anterior, ubicándose también en un friso situado en la zona media de la pared, pero en este caso de la habitación $\mathrm{V}$.

En primer lugar contamos con dos fragmentos informes de grandes $(14 \times 16 \mathrm{~cm})$ y pequeñas dimensiones de pintura mural ${ }^{12}$. En ellos se conserva el tránsito o nexo de unión del zócalo a la zona media que es aproximadamente de $1 \mathrm{~cm}$ de anchura y le sigue un campo amarillento ocre de 6,5-7,7 cm de anchura. Sobre este campo y a modo de soporte flotante, como una especie de nube de color rojo oscuro o castaño de $0,4 \mathrm{~cm}$ de anchura, reposa la planta de un pie derecho de perfil que mide desde el talón al único dedo que conservamos, alrededor de $8 \mathrm{~cm}$ de longitud (Fig. 9).

\footnotetext{
${ }^{11}$ Aprovecho esta oportunidad para dar nuevamente mi agradecimiento más sincero al Director de la Casa de Cultura de Yecla, Liborio Ruiz Molina, por haberme facilitado el estudio del material proveniente de la villa romana de Los Torrejones.

${ }_{12}$ Ficha técnica: Caja 49. 1/1, cuadrícula E6 y habitación $V$, $\sin$ referencia de año. $N^{0}$ inventario provisional: $5 / 4(a-b)(15$ y 38), ubicado en la pared sur. Grosor: $1^{\mathrm{a}}$ capa: $0,2 \mathrm{~cm} ; 2^{\mathrm{a}}$ capa: $0,4 \mathrm{~cm} ; 3^{a}$ capa: $1,3 \mathrm{~cm} ; 4^{a}$ capa: $1,4 \mathrm{~cm}$ con reverso plano; $5^{a}$ capa: $0,5 \mathrm{~cm}$ de lechada de cal que oculta una fase pictórica precedente. Contamos con un grosor total aproximado de 4,3-4,5 cm, mortero compuesto por una gran cantidad de oquedades y de aspecto poroso.
} 


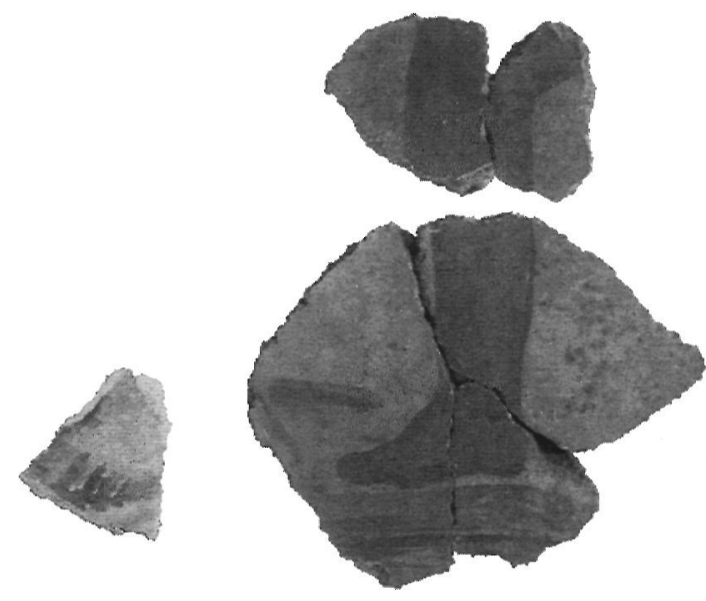

Figura 10: Representación de otros pies de perfil y de frente (Foto: A. Fernández).

Se trata de la representación del pie de un personaje masculino a escala $1 / 4$ ó $1 / 5$ de la real, por tanto de aproximadamente $60-70 \mathrm{~cm}$ de estatura o de altura total. La otra pieza conserva la representación de otro pie ejecutado con tonos más suaves y de forma más acuosa, quizás por haber empleado el artesano una mayor cantidad de agua en la mezcla. Éste, sin ningún tipo de calzado, es de color rosa palo con pinceladas blancas que imitan el tono de la carne. No obstante, estos no son los únicos fragmentos con representaciones de pie que aparecen en estas estancias (Fig. 10).

En segundo lugar conservamos ocho fragmentos informes de medianas y pequeñas dimensiones de pintura mural ${ }^{13}$. Sobre un enlucido de fondo blanco se representan distintas partes del cuerpo humano para cuya ejecución se utilizan tonos rosáceos y blancos en su interior y pinceladas rojo oscuro o castaño para dibujar los contornos exteriores o algún motivo interior como pueda ser la musculatura. De entre estas piezas, diferenciamos una rodilla (pieza $n^{\circ} 33$ en el inventario antiguo del museo $)^{14}$, parte del muslo de una pierna, la mitad inferior de un rostro visto de frente y con la parte superior del tronco ( $\mathrm{n}^{\circ} 34$ inv. ant.) y lo que pudiera ser el cabello de otro personaje masculino ( $n^{\circ} 17$ inv. ant.). Otro de los fragmentos, uno de los más significativos por conservarse casi completo en toda su altura ( $n^{\circ} 35 \mathrm{inv}$. ant.), muestra la representación de un personaje desnudo que lleva cordón y colgante alrededor del cuello así como sendos guantes en sus manos (Fig. 11). Asimismo, observamos cómo se ha querido representar la violencia del combate, haciendo sangrar la nariz de la que surgen unas pinceladas muy finas que simulan la caída de la sangre. Por lo demás, aparece desnudo y se

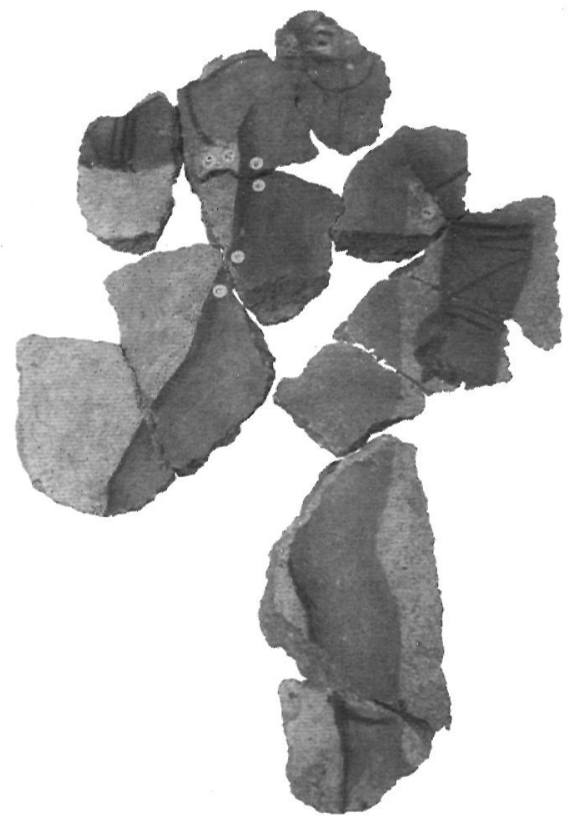

Figura 11: Representación de un púgil de frente con los guantes de boxeo y totalmente desnudo (Foto A. Fernández).

observan las huellas de las cerdas de la brocha del artesano que lo pintó, lo que nos llevaría a pensar que la figura se realizó cuando el enlucido estaba ya seco. Sin embargo, recientes analíticas demuestran que no es así, sino que fue pintado al fresco y que el paso del tiempo y su pésimo estado de conservación han hecho que parezca estar pintado en seco.

Por otra parte, contamos con seis fragmentos informes y de pequeñas dimensiones de pintura mural que también representan sobre un enlucido de fondo blanco distintas partes del cuerpo humano desnudo ${ }^{15}$. Únicamente distinguimos dos representaciones correspondientes a los tobillos de dos piernas diferentes que llevan sendos lazos anudados de color rojo, quizás a modo de distintivo o por una normativa impuesta en este tipo de actividades. Asimismo, de este último grupo de fragmentos conservamos su posible ubicación en la habi-

\footnotetext{
${ }^{13}$ Ficha técnica: Caja 49. 1/1, cuadrícula E6 y habitación $V$, sin referencia del año: $N^{0}$ inventario provisional: $5 / 5(a-h)(6$, 14, 21, 22, 24). Grosor: $1^{\text {a }}$ capa: $0,05 \mathrm{~cm} ; 2^{\text {a }}$ capa: $0,9-1,3$ $\mathrm{cm}$; $3^{\text {a }}$ capa: $1,3 \mathrm{~cm}$; $4^{\text {a }}$ capa: $0,9 \mathrm{~cm} ; 5^{\text {a }}$ capa: $1,4 \mathrm{~cm}$. En general, los fragmentos presentan un grosor aproximado de $3,3 \mathrm{~cm}$, con reverso plano y las improntas en positivo del piqueteado de la fase pictórica anterior.

${ }^{14}$ En lo sucesivo la nota aparecerá abreviada en el texto con $\mathrm{n}^{\circ}$ inv. ant.

${ }^{15}$ Ficha técnica: Caja 49. 1/1, cuadrícula E6 y habitación $V$, sin referencia del año: $N^{\circ}$ inventario provisional: $5 / 5(i-n)(6$, $25,28,36,38,39)$. Grosor: $1^{\text {a }}$ capa: $0,1 \mathrm{~cm} ; 2^{\mathrm{a}}$ capa: $1,2-1,5$ $\mathrm{cm} ; 3^{\mathrm{a}}$ capa: $1,5-2 \mathrm{~cm}$ de grosor conservado con reverso plano.
} 

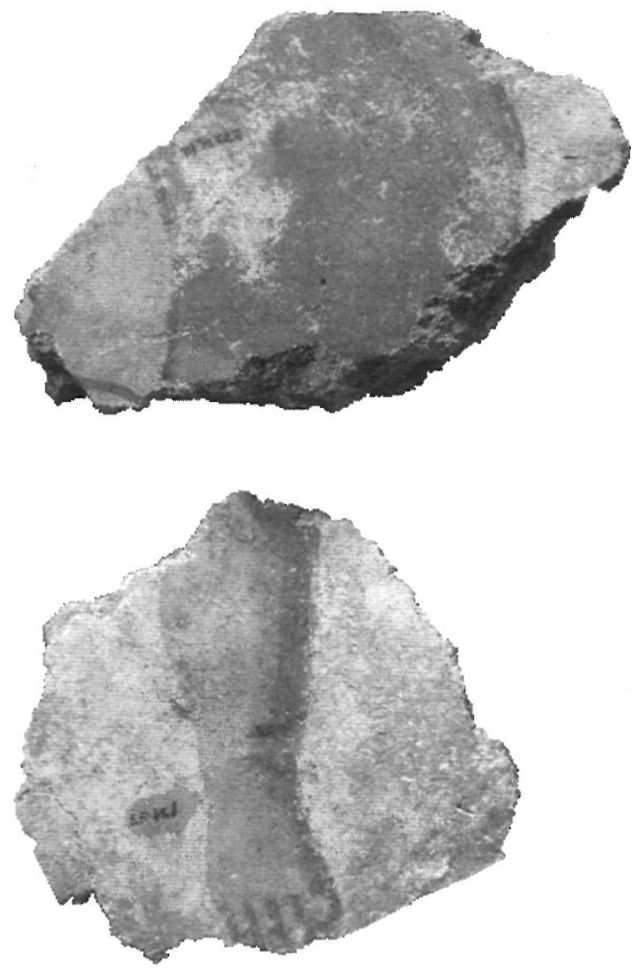

Figura 12: Representación de una pierna de frente con un elemento circular al lado (Foto: A. Fernández).

tación $V$, ya que las piezas están sigladas con una "S", posiblemente porque decorarían la pared sur.

De la misma habitación y provenientes también de la pared sur, conservamos cuatro fragmentos informes -que pegan por parejasde grandes $(15 \times 16$ y $13 \times 21 \mathrm{~cm})$ y pequeñas dimensiones de pintura mural correspondientes nuevamente a distintas partes del cuerpo desnudo de figuras masculinas ${ }^{16}$. Se trata de una pierna derecha y de frente con sus cinco dedos, contorneada de castaño y donde se observa a través de las pinceladas que la dirección de la luz vendría de la derecha. Ésta se coloca sobre un fondo blanco y está rodeada por trazos ocres que no acertamos a definir. La otra pierna se dibuja sobre un fondo amarillento ocre y también presenta el típico lazo anudado al tobillo, aunque desconocemos si se sitúa de frente o de perfil. Del otro fragmento desconocemos la parte del cuerpo que representa, lo que sí está claro es que parece una articulación por el juego de luz y sombra así como por la presencia de un lazo. Junto a esta figura conservamos otro elemento curvo y de color amarillo ocre contorneado de rojo, en cuyo interior contiene alguna que otra pincelada de color rojo. Este último elemento podría representar algún instrumento de lucha, tal vez un escudo de al menos $20 \mathrm{~cm}$ de diámetro según el arco de circunferencia que nos queda conservado (Fig. 12). Esto nos llevaría a pensar en la representación de diferentes tipos de juegos físicos o atléticos además del pugilato, como pueda ser la lucha.

Grupo C: el siguiente grupo de fragmentos, alrededor de ciento sesenta y uno, corresponde a la habitación denominada como "E" y a cajas que no presentan referencia alguna, pero cuya representación es la misma que la del grupo anterior, por tanto podemos considerar que la estancia "E" y la "V" son la misma o son contiguas y el derrumbe es posible que sea de un muro compartido. Si ambas habitaciones son una sola, la única diferencia es que algunos de los fragmentos podrían pertenecer a la pared oeste de la misma, pues van siglados con una "W". El hallazgo de estas piezas en la pared oeste o próximos a ésta quiere decir que la secuencia figurada podría abarcar gran parte de la estancia a modo de friso corrido, pues tanto la pared norte como la sur también presentan esta misma escena figurada.

En primer lugar conservamos un fragmento informe y de muy pequeñas dimensiones de pintura mural ${ }^{17}$. Sobre un enlucido de fondo de color carne aparecen una serie de pinceladas rojas sin forma definida que pertenecen a alguna parte de un cuerpo desnudo que desconocemos.

En segundo lugar conservamos un total de veintisiete fragmentos informes de pequeñas y muy pequeñas dimensiones de pintura mural correspondientes a distintas partes del cuerpo y en mayor número a articulaciones ${ }^{18}$.

\footnotetext{
${ }^{16}$ Ficha técnica: Caja 49. 2/5, Balazote 1970, IV (tuberia) (61-70). No inventario provisional: $5 / 5(\tilde{n}-q)(1,6,12,14,61$, $66,72,74)$. Grosor: $1^{\text {a }}$ capa: $0,05 \mathrm{~cm} ; 2^{\text {a }}$ capa: $0,5 \mathrm{~cm} ; 3^{a}$ capa: $0,7-1,1 \mathrm{~cm} ; 4^{\text {a }}$ capa: $2,3-3 \mathrm{~cm}$ de grosor conservado con reverso plano y las improntas en positivo del piqueteado de la fase anterior; $5^{\text {a }}$ capa: $3,4-4$ ó $3-3,8 \mathrm{~cm}$ de grosor conservado con restos de pigmento rojo de esa decoración pictórica precedente.
}

17 Ficha técnica: Caja 49. 2/8. Balazote 1972, habitación E, 5 bn y 2 bn (75-132). $N^{\circ}$ inventario provisional: $E / 5(r)$ ( 88 pared oeste). Grosor: $1^{a}$ capa: 0,4-0,8 cm; $2^{a}$ capa: $1,2-1,4 \mathrm{~cm}$; $3^{a}$ capa: $1-1,5 \mathrm{~cm}$ de grosor conservado sin reverso liso $\mathrm{ni}$ en espiga.

${ }^{18}$ Ficha técnica: Caja 49. 3/2, sin referencia de ningún tipo (301-393). Al número 350 corresponden tres fragmentos que encajan, y el número 393 representa un florón o rosetón esquematizado. $N^{\circ}$ inventario provisional: $5\left(s-r^{\prime}\right)$. Grosor: $1^{a}$ capa: $0,05-0,1 \mathrm{~cm} ; 2^{a}$ capa: 0,9-1 cm; $3^{\text {a }}$ capa: $1-1,2 \mathrm{~cm}$ de mortero con gran cantidad de cal en su composición; $4^{a}$ capa: $1,1 \mathrm{~cm}$ de grosor conservado con el reverso plano y las improntas en positivo del piqueteado de la fase pictórica anterior. 


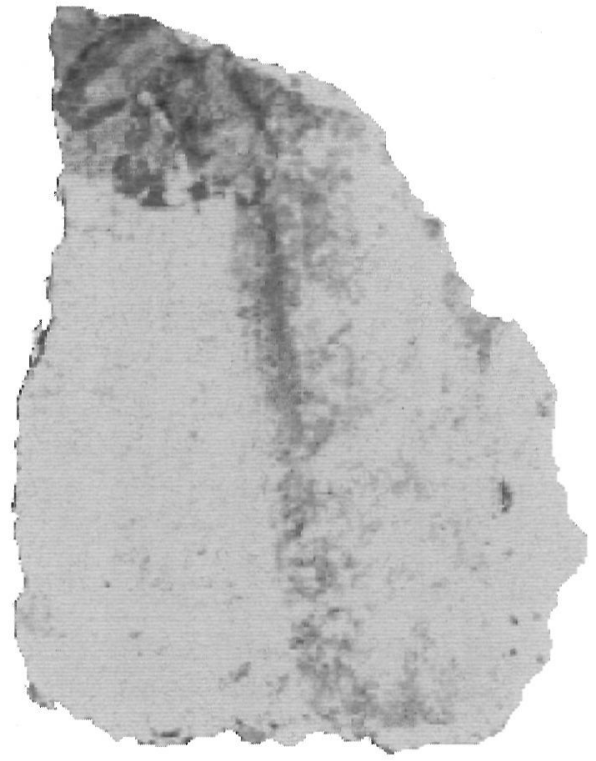

Figura 13: Fragmento con la representación de los genitales de un deportista (Foto: A. Fernández).

Asimismo, dos de las piezas parecen representar los atributos masculinos o genitales de forma muy somera, es decir, apenas se dejan apreciar en la entrepierna (Fig. 13). En cuanto a su ejecución técnica, se sigue el mismo método de remarcar los contornos con color rojizo o castaño oscuro y el interior en color rosa palo o carne.

También contamos con otro grupo de dieciséis fragmentos informes y de muy pequeñas dimensiones de pintura mural que representan distintas partes del cuerpo y, en algún caso, nuevamente el atributo masculino, así como los típicos lazos anudados a la altura del tobillo ${ }^{19}$.

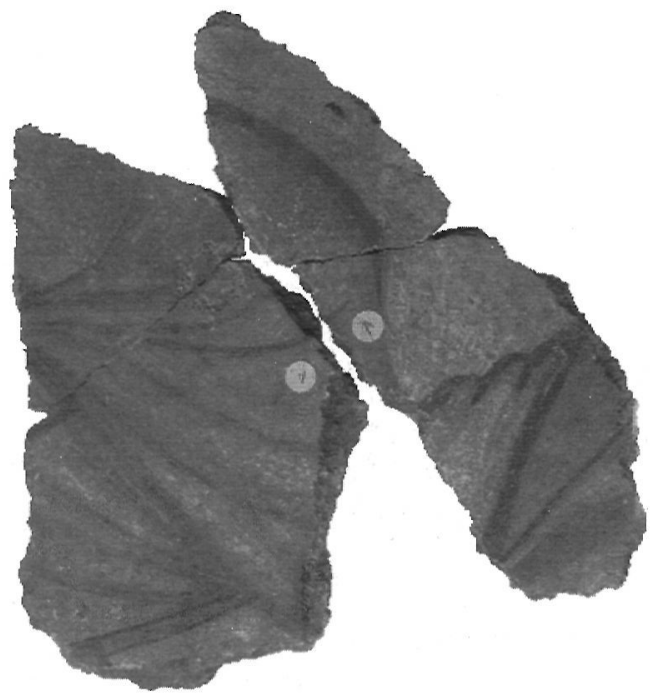

Figura 14: Parte de la toga de un árbitro del combate (Foto: A. Fernández).

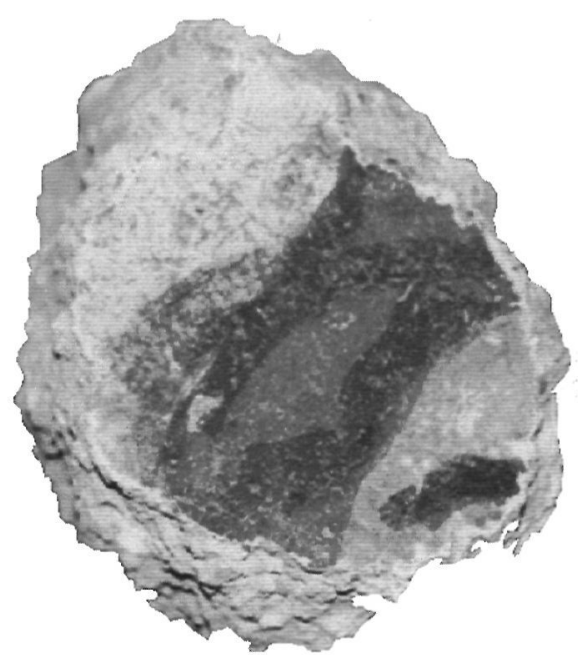

Figura 15: Representación de parte de una cabeza de frente (Foto: A. Fernández).

Por su parte, conservamos dos fragmentos informes y de pequeñas dimensiones de pintura mural en la que, sobre un enlucido de fondo blanco y mediante diversos filetes de 0,3$0,5 \mathrm{~cm}$ de anchura en color ocre verdoso, se simulan los pliegues de una toga que caen desde el hombro ${ }^{20}$. Se trata posiblemente de la vestimenta del árbitro o de un personaje que observa las actividades deportivas, tal vez el único personaje figurado de la escena que no iría desnudo (Fig. 14).

Conservamos otro grupo de fragmentos, un total de veintiséis informes de pequeñas y muy pequeñas dimensiones de pintura mural ${ }^{21}$. Una de las piezas nos muestra el lateral derecho de una cabeza de un personaje -ceja y cabello- ( $n^{\circ} 641$ inv. ant.) (Fig. 15): cabello de

19 Ficha técnica: Caja 49. 3/3, sin referencia de ningún tipo (394-442). $N^{\circ}$ inventario provisional: $5\left(s^{\prime}-h^{\prime \prime}\right)$. Grosor: $1^{\text {a }}$ capa: $0,05 \mathrm{~cm} ; 2^{a}$ capa: $0,7 \mathrm{~cm} ; 3^{a}$ capa: $0,1 \mathrm{~cm}$ de lechada de cal que tapa la fase pictórica anterior; $4^{\mathrm{a}}$ capa: $1,1 \mathrm{~cm} ; 5^{\mathrm{a}}$ capa: $1,7-2,2 \mathrm{~cm}$ de grosor conservado con reverso plano e improntas en positivo de la primitiva fase pictórica. Otros fragmentos presentan esta última capa a los $2-2,2 \mathrm{~cm}$ de grosor.

20 Ficha técnica: Caja 49. 3/3, sin referencia de ningún tipo (394-442). $\mathrm{N}^{\circ}$ inventario provisional: $24(\mathrm{a}-\mathrm{b})$, piezas 414 y 419 del inventario antiguo del museo. Grosor: $1^{\text {a }}$ capa: 0,05 $\mathrm{cm}$; $2^{\mathrm{a}}$ capa: $1,5 \mathrm{~cm} ; 3^{\mathrm{a}}$ capa: $1,2 \mathrm{~cm}$ de grosor conservado con reverso plano.

${ }^{21}$ Ficha técnica: Caja 49. 4/5. Campaña de 1972, cuadrícula E6, habitación $\mathrm{E}$, nivel IIb (640-687). No inventario provisional: $E / 5\left(n^{11}-k^{111}\right)$. Grosor: $1^{\text {a }}$ capa: $0,05 \mathrm{~cm} ; 2^{a}$ capa: 0,4 $\mathrm{cm} ; 3^{a}$ capa: $0,2-0,3 \mathrm{~cm}$ de lechada de cal; $4^{a}$ capa: $1,1 \mathrm{~cm}$ de mortero con restos de materia vegetal (paja) descompuesta; $5^{\text {a }}$ capa: $1,1-1,4 \mathrm{~cm}$ de grosor conservado con reverso plano y las huellas en positivo del piqueteado de una fase pictórica anterior. 3,4-3,7 cm de grosor conservado con las misma características. 


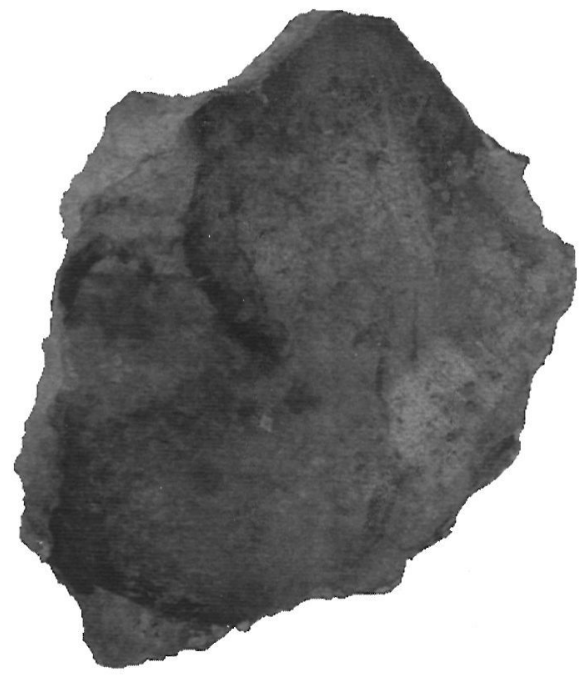

Figura 16: Representación de un bíceps de uno de los deportistas (Foto: A. Fernández).

color rojo-castaño y ocre-amarillento con rizos hechos mediante unas leves pinceladas curvas y rostro de color rosáceo imitando de forma muy realista la tez humana. Otro fragmento nos muestra la parte superior de una cabeza de la que se distingue únicamente el cuello, mientras que otra pieza presenta alguna de las extremidades donde se observa la musculatura a través de las pinceladas curvas y un lazo que no está completo (Fig. 16). Dentro de este grupo conservamos dos piezas que muestran restos de letras capitales, una de ellas localizada en el ángulo norte de la pared oeste $\left(n^{\circ} 662\right.$ inv. ant.) y otra en la pared norte ( $n^{\circ} 663$ inv. ant.), por tanto, podemos decir que junto a la escena figurada podría localizarse algún epígrafe que interpreta dicha escena o relacionado con la misma.

Algunos de estos últimos fragmentos parecen ir barnizados, pues se observan las cerdas de la brocha en distintas direcciones; sin embargo, las recientes analíticas demuestran que en la época en que se hallaron, fueron consolidados con una solución que actualmente puede retirarse sin complicación alguna.

Al siguiente grupo corresponden un total de sesenta y un fragmentos divididos entre las cuatro paredes de esta estancia ${ }^{22}$. Siete de éstos son informes de medianas y muy pequeñas dimensiones, correspondientes a distintas partes del cuerpo masculino de una escena figurada $^{23}$. Una de las piezas conserva el ojo y la ceja izquierda, posiblemente relacionada con el ojo derecho que vimos anteriormente pues parecen tener la misma escala. También con-

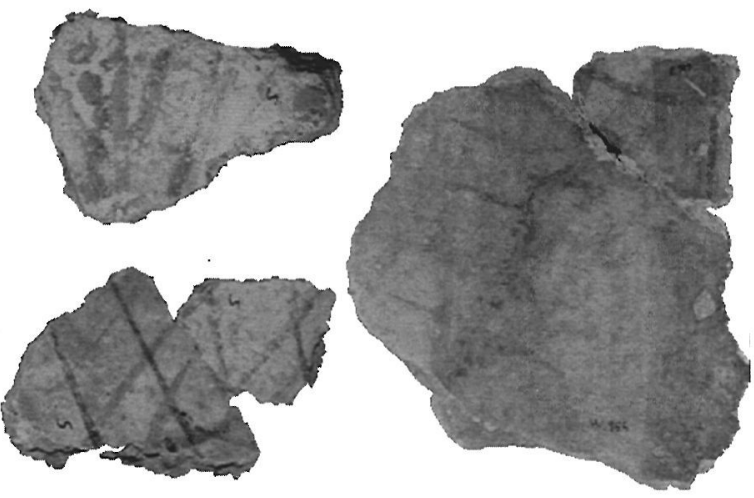

Figura 17: Fragmentos con la representación de las hojas de una palma de la victoria (Foto: A. Fernández).

servamos dos pies izquierdos de tamaño diferente ( $n^{\circ} 639 b$ y $655 b$ inv. ant.) y el ángulo superior izquierdo con cabello rizado y ceja de otra cabeza. En cuanto a los pies, éstos se apoyan sobre una superficie representada en color ocre-verdoso y amarillento, tal vez la imitación de la arena de un espacio abierto del tipo de una palestra o anfiteatro. Por otra parte, tres de los fragmentos informes y de muy pequeñas dimensiones de pintura mural representan un entramado o enrejado en forma de red sobre un enlucido de fondo blanco, perteneciente posiblemente a la pared sur ${ }^{24}$. Éste se representa mediante finas trazas o filetes de no más de $2 \mathrm{~mm}$ de anchura y en color verde claro y amarillo, tal vez un instrumento de lucha cuerpo a cuerpo -una red- (Fig. 17). No obstante, tampoco podemos descartar la representación de los tallos de una palma que simboliza la victoria en el combate o la lucha.

Este tipo de representación de la victoria no sería el único elemento que la simboliza, pues contamos con un fragmento en el que

\footnotetext{
22 Piezas número $626 \mathrm{~b}$ a $629 \mathrm{~b}$ del inventario antiguo del museo corresponden a la pared norte; los fragmentos $630 \mathrm{~b}$ a $638 \mathrm{~b}$ pertenecen a la pared oeste; las piezas $639 \mathrm{~b}$ a $647 \mathrm{~b}$ a la pared este y las $648 \mathrm{~b}$ a $667 \mathrm{~b}$ no presentan referencia.

${ }^{23}$ Ficha técnica: Caja 49. 5/6. Campaña de 1973, cuadrícula E6, habitación E, nivel Ilb (626 bis a 667 bis*). No inventario provisional: $E / 5\left({ }^{\prime \prime \prime}-q^{\prime \prime \prime}\right)$. Grosor: $1^{\text {a }}$ capa: $0,05 \mathrm{~cm} ; 2^{a}$ capa: $0,7 \mathrm{~cm} ; 3^{a}$ capa: $0,2 \mathrm{~cm}$ de lechada de cal; $4^{a}$ capa: $1,2 \mathrm{~cm}$; $5^{\text {a }}$ capa: $1,5 \mathrm{~cm} .4,3 \mathrm{~cm}$ de grosor conservado con reverso plano y las improntas en positivo de una fase pictórica precedente.

${ }^{24}$ Ficha técnica: Caja 49. 5/6. Campaña de 1973, cuadrícula E6, habitación E, nivel IIb (626 bis a 667 bis*). No inventario provisional: $E / 33(\mathrm{a}-\mathrm{c})$. Grosor: $1^{\mathrm{a}}$ capa: $0,05 \mathrm{~cm} ; 2^{\mathrm{a}}$ capa: $0,4 \mathrm{~cm} ; 3^{\mathrm{a}}$ capa: $0,6-0,7 \mathrm{~cm} ; 4^{\mathrm{a}}$ capa: $1,4 \mathrm{~cm}$ de grosor conservado con reverso plano.
} 


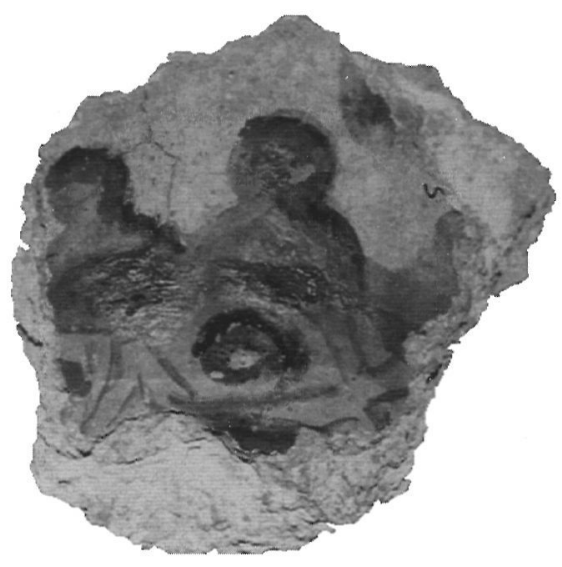

Figura 18: Representación de parte de una corona de la victoria (Foto: A. Fernández).

se representa una especie de corona (Fig. 18) así como otro con una mano que agarra un elemento vegetal (Fig. 19).

El siguiente grupo de fragmentos corresponde casi íntegramente a la pared oeste donde se representa una escena de pugilato en la que se conservan brazos, bíceps ( $n^{\circ} 670$ inv. ant.) y puños protegidos por una especie de guante de cuero sujeto a la mano mediante cintas entrecruzadas. En líneas generales, se trata de dieciocho piezas informes -dos de ellas pegan- de grandes $(17 \times 12 \mathrm{~cm})$, medianas y pequeñas dimensiones de pintura mural ${ }^{25}$. Conservamos un total de tres guantes de púgil con una especie de clavos o pinchos que sobresalen, uno de ellos completo y perteneciente a una mano izquierda (Fig. 20). El cuero de los guantes está representado mediante un color rosáceo o violáceo y el contorno en rojo, así como las cintas que tienden a alcanzar el color negro para resaltar el volumen. Éstas repiten siempre el mismo esquema, rodean antebrazo y muñeca con dos vueltas y se cruzan en el trayecto ${ }^{26}$.

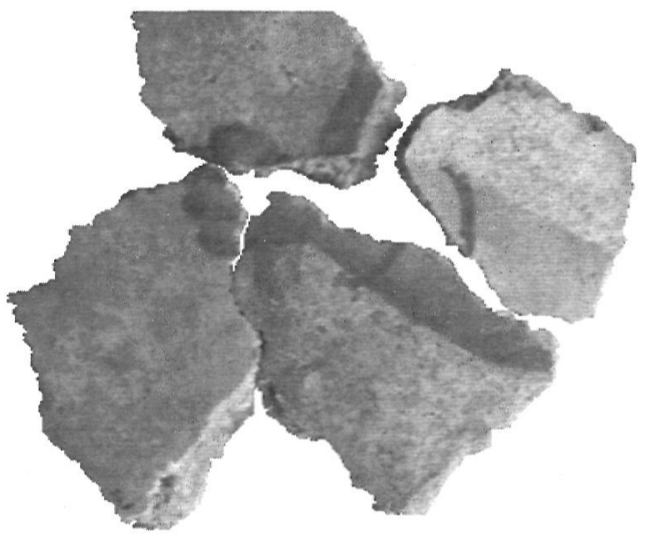

Figura 19: Representación de un brazo con cinta anudada a la muñeca y espiga vegetal agarrada en la mano (Foto: A. Fernández).

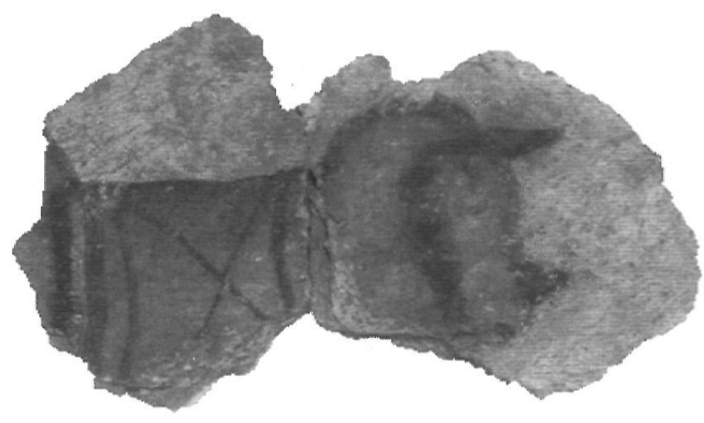

Figura 20: Guante de púgil con representación de clavos (Foto: A. Fernández).

Otros treinta y un fragmentos informes y de pequeñas dimensiones de pintura mural pertenecen a la misma escena figurada ${ }^{27}$. Algunas de las piezas representan distintas partes del cuerpo, sobre todo bíceps, y otras deben corresponder a telas portadas por el magistrado o árbitro anteriormente mencionado. Conservamos también parte de la indumentaria de algún luchador, consistente en una coraza de color rojo que cubriria probablemente el brazo y de la que penden una serie de pequeñas gotas (Fig. 21).

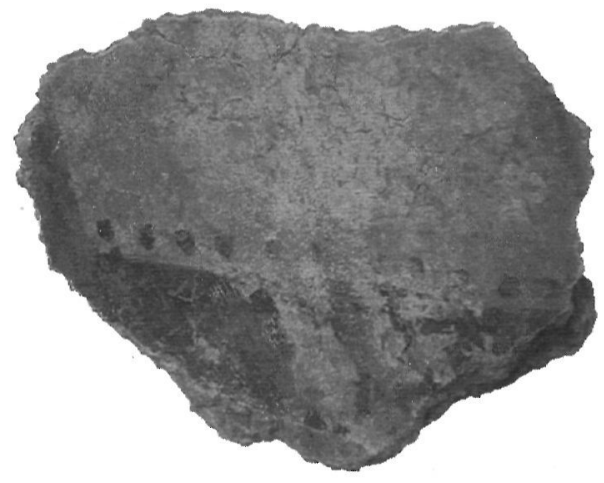

Figura 21: Fragmento de un brazo acorazado (Foto: A. Fernández).

25 Ficha técnica: Caja 49. 5/7. Campañas de 1972 Y 1973 , cuadrícula E6, habitación E, nivel Ilb (668 bis a 695 ó 668 bis-687 bis y 688-695). $N^{\circ}$ inventario provisional: $E / 5\left(r^{\prime \prime \prime}-h^{\prime V}\right)$. Grosor: $1^{a}$ capa: $0,05 \mathrm{~cm} ; 2^{a}$ capa: $0,4 \mathrm{~cm} ; 3^{a}$ capa: $1 \mathrm{~cm} ; 4^{a}$ capa: 1 ' $4 \mathrm{~cm} ; 5^{\mathrm{a}}$ capa: 2,4-2,7 cm de grosor conservado $\sin$ reverso plano ni en espiga. La capa superficial o superficie pictórica presenta una gran cantidad de carbonatos.

26 Tras la reciente restauración que se lleva a cabo actualmente por parte de $D^{a}$. $M^{a}$. Fernanda Pascual Martínez, se comprueba sin lugar a dudas, que estos fragmentos se corresponden con el fragmento de la cabeza del púgil sangrante correspondiente al grupo $\mathrm{C}$, anteriormente mencionado.

${ }^{27}$ Ficha técnica: Caja 49. 5/8. Campañas de 1972 y 1973 , cuadrícula E6, habitación E, nivel Ilb (696-747). No inventario provisional: $E / 5\left(i^{\vee v}-I^{\vee}\right)$. Grosor: $1^{\mathrm{a}}$ capa: $0,05 \mathrm{~cm} ; 2^{\mathrm{a}}$ capa: $0,4 \mathrm{~cm}$; $3^{a}$ capa: $0,6-0,7 \mathrm{~cm} ; 4^{a}$ capa: $0,8-0,9 \mathrm{~cm} ; 5^{a}$ capa: $1,4 \mathrm{~cm}$ de grosor conservado sin el reverso completo. 


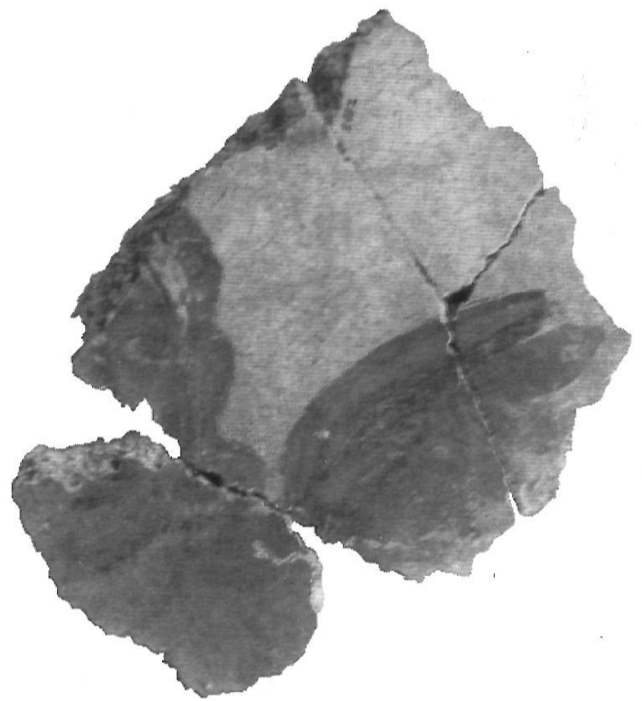

Figura 22: Fragmento de un personaje alado (Foto: A. Fernández).

También contamos con dos nuevos fragmentos informes y de pequeñas dimensiones de pintura mural sobre un enlucido de fondo blanco ${ }^{28}$ : en el primero de ellos se representa un panel en color ocre rojizo que podría corresponder al suelo o arena de un área abierta, bajo la cual se representa una banda negra de 1,4 $\mathrm{cm}$ de anchura y una banda roja de $4 \mathrm{~cm}$ de anchura mínima conservada de encuadramiento exterior de dicho panel ( $n^{\circ} 872$ inv. ant. pared sur); el otro conserva una zona indeterminada de un personaje masculino y un objeto ocre castaño, posiblemente un instrumento de lucha ( $n^{\circ} 862$ inv. ant., pared norte).

En último lugar conservamos trece fragmentos informes -tres de ellos pegan- de medianas y pequeñas dimensiones de pintura mural con distintas partes de un cuerpo masculino que no alcanzamos a determinar ${ }^{29}$. Uno de ellos conserva la parte izquierda de un rostro y cabeza de un personaje con colgante en el cuello y del cual nace un ala muy pequeña ( $n^{\circ} 1186$ inv. ant.) (Fig. 22). Un dato curioso es el hecho de que el personaje alado, tal vez una alegoría, está representado a la misma escala que el resto de los personajes y podría unir con el fragmento representado en la figura 3 como ya dijimos en su momento.

Grupo D: se trata de parte de la pintura mural recuperada de la campaña de 1972, en la que la bolsa no presenta referencia alguna sino que se muestra únicamente la numeración de los fragmentos que están sin etiquetar $\left(n^{\circ}\right.$ 626-630 inv. ant.). La mayoría de ellos representa figuras humanas correspondientes tal vez a la habitación "E" o "V".

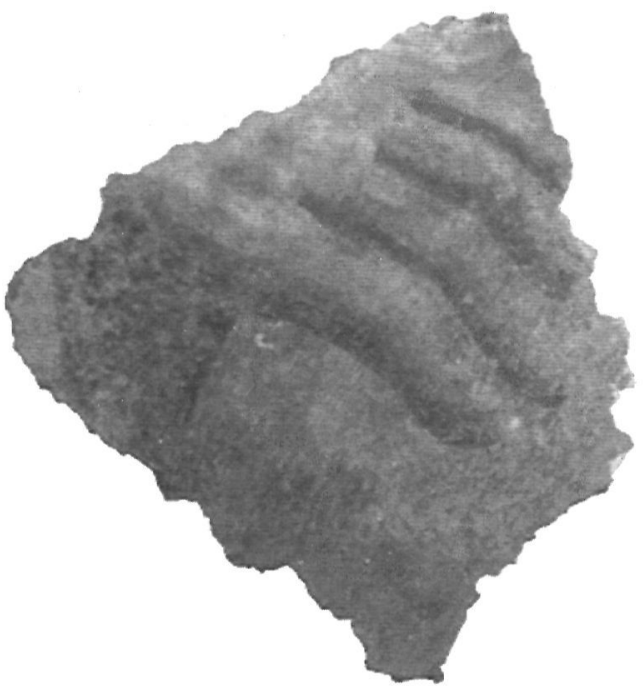

Figura 23: Fragmento de una mano (Foto: A. Fernández).

Conservamos solamente cinco fragmentos informes de pequeñas y muy pequeñas dimensiones de pintura mural que representan distintas partes del cuerpo de varios personajes en una ejecución de muy buena calidad ${ }^{30}$. Contamos con los dedos de un pie y parte de dos pies enfrentados -uno de ellos mide aproximadamente $5,2 \mathrm{~cm}$ de longitud- que reposan sobre un campo amarillento ocre, tal vez la arena de la palestra ( $n^{\circ} 626-627$ inv. ant.). También conservamos la representación de una mano derecha de 4,8-5 cm de longitud $\left(n^{\circ} 628\right.$ inv. ant.) (Fig. 23), así como con los restos de una nariz y boca dibujados de perfil ( $n^{\circ} 629$ inv. ant.).

En cuanto al tema iconográfico en las termas, estamos acostumbrados a ver representaciones de temas de la naturaleza, especialmente marinos o fluviales; sin embargo, este tipo de decoraciones que representan actividades termales -de carácter higiénico o deportivo como las nuestras-, son muy escasas

${ }^{28}$ Ficha técnica: Caja 50. 2/2. Campaña de 1972, cuadrícula $E 6$, habitación $E$, nivel II (860-881). No inventario provisional: $E / 5\left(n^{\vee}-\tilde{n}^{v}\right)$. Grosor: $1^{a}$ capa: $0,05 \mathrm{~cm} ; 2^{a}$ capa: 0,2-0,4 $\mathrm{cm}$; $3^{a}$ capa: $0,1 \mathrm{~cm}$ de lechada de cal; $4^{\mathrm{a}}$ capa: $0,9-1,1 \mathrm{~cm}$; $5^{\text {a }}$ capa: $1,2-1,3 \mathrm{~cm}$ de grosor conservado con reverso plano; $6^{\text {a }}$ capa: $1,6 \mathrm{~cm}$ de grosor conservado sin reverso en espiga, se trata de la tierra de unión con el alzado de adobe del muro.

${ }^{29}$ Ficha técnica: Caja 51. 1/5. Campaña de 1972, cuadrícula E6, habitación $E$, nivel II (1161-1197). No inventario provisional: $E / 5\left(o^{V}-a^{V l}\right)$.

30 Ficha técnica: Caja 49. 4/4. Campaña de 1972 (526-639). $\mathrm{N}^{\circ}$ inventario provisional: $72 / 5\left(\mathrm{i}^{\prime \prime}-\mathrm{m}^{\mathrm{II}}\right)$. Grosor: $1^{\mathrm{a}}$ capa: 0,05 $\mathrm{cm}$. 2-2,1 cm de grosor conservado con reverso plano. 
en la pintura provincial, por tanto el caso de Balazote es excepcional y puede considerarse como el hallazgo de un tesoro arqueológico.

En definitiva, la escena a la que pertenecen todos los personajes de los grupos en los que hemos dividido los fragmentos hallados, se desarrolla sobre un fondo de color blanco y con una estructura que sería probablemente corrida y no compartimentada en paneles grandes.

El rostro y el resto del cuerpo de los diversos personajes mostrados aparecen representados con unos pigmentos empleados de forma corriente en el mundo romano. Se trata esencialmente de diversos tonos de color rojo, ocre y color ocre y rosáceo para simular el tono de la carne, y de blanco, verde y amarillento para los fragmentos que representan las túnicas, tonos estos últimos muy semejantes a los usados por ejemplo en la vestimenta del personaje femenino y de perfil de la anteriormente citada villa de Los Torrejones. Sin embargo, y con respecto a ésta, la de Balazote muestra también otras muchas diferencias, no solamente formales sino también en la calidad de la ejecución de la pintura, pues ésta se ejecuta con unas pinceladas muy pastosas que dejan entrever las cerdas del instrumento con el que se realiza. Esto hace pensar que posiblemente no sufrirían ningún tipo de alisamiento e indica que su datación sería incluso posterior a la de la anteriormente mencionada villa romana de Yecla.

En cuanto a las escenas de aseo, conservamos únicamente un ejemplo temprano en un ábside del caldarium de la Casa del Menandro; sin embargo, las escenas que representan los ejercicios gimnásticos que antecedían a los baños y que se llevaban a cabo en la palestra, son más numerosas. Ejemplos de éstos, pero representados de forma aislada, los encontramos generalmente realizados en estuco como por ejemplo dos atletas sin finalizar en el 79 d.C. y dos púgiles procedentes de la bóveda del caldarium de la villa de Petraro (Camardo et alii, 1989, 84, figs. 110-111; Mielsch, 1975, 129, lám. 30), muy semejantes a los encontrados en las salas anexas a la palestra de las termas de Stabia de Pompeya (Mielsch, 1979, 75, figs. 60b-d); no obstante, también los conservamos en la pintura. Ejemplos en esta última técnica de revestimiento los encontramos en esta misma ciudad, concretamente en la estancia que da acceso al sector masculino de las termas de Stabia donde se muestran parejas de luchadores en el centro de los paneles separados por escorzos arquitectónicos (De Vos, 1979, 84-85, fig. 26), y en la palestra de los Baños del Sarno en las que conservamos arquitecturas ficticias del cuarto estilo pompeyano con representaciones de dos apoxiomenoi o atletas usando los estrígilos, un discóbolo y un atleta que abate a un contrario (Gallo, 1991, 41-42). Pero estas escenas figuradas no comprenden solamente atletas, sino que también podemos encontrar otro tipo de personajes que pueden ser considerados como el precedente del personaje alado que aparece en las termas de Balazote. Así, en la villa de San Marco, a unos pocos kms de Pompeya, el atrio por el que se ingresa a las termas está decorado, además de con un púgil sentado y otro de pie, con amorcillos en actitud de lucha (Camardo et alii, 1989, figs. 50-51).

En cuanto a las escenas de púgiles las podemos encontrar también en Pompeya, concretamente en el caldarium de las termas privadas de la casa del Menandro, donde además de dos púgiles, se representan dos luchadores afrontados, un discóbolo y un atleta en el centro de los paneles verdes de la zona media de la pared, así como en la casa VII, LXIII, 281 (Rodrigo y Jiménez, 2004, 309), donde un púgil porta palma, guantes y corona. Otra de las figuras que aparecen en Balazote es la del árbitro, y también en Pompeya, en la casa del Palestrista, se representan luchadores y árbitros (Gusman, 1900, 169). De otras casas de esta misma ciudad proceden un discóbolo (Helbig, 1868, 1508; Finati et alii, 1854-1857, IX, 12), un discóbolo y atleta ejercitándose con los puños (en RM, 1888, 202), temas que también suelen representarse en este tipo de edificios termales o zonas deportivas; no obstante, los temas que suelen aparecer en las estancias termales o relacionadas con el agua van más allá de los mencionados anteriormente y suelen ser variados como queda constatado en la serie de artículos recogidos por C. Guiral Pelegrín en su ponencia sobre el programa decorativo-ornamental de las termas romanas celebrado en Gijón (Guiral, 1999, 115-121).

Estos espectáculos de juegos en sus diferentes fases, juegos gimnásticos o "gymnasia" y los combates pugilísticos o pugiles, que es el tema que aparece en Balazote, surgen en todo tipo de representaciones, como por ejemplo sobre las terracotas decorativas de los jardines de Sallustio en la Roma de época tardorepublicana (Gardiner, 1967, fig. 71, 109), o en un pelike ático de figuras rojas del pintor de Peleo con el coronamiento de un atleta vence- 
dor proveniente de Taranto (450-430 a.C.) y de $34 \mathrm{~cm}$ de altura. También contamos con una estatua broncínea del púgil de las termas del siglo IV a.C. y de $128 \mathrm{~cm}$, proveniente de las pendientes del Quirinal y actualmente localizado en las termas de Diocleciano. No obstante, algunos de los ejemplos más llamativos proceden de mosaicos como el de Tusculum con ejercicios de atletas (en Mon. Inst. VII, 1863, lám. 82; en Annali, 1863, 397; en RA, 1904, I, 308; en Jahrb, 1900, 197), el del siglo III d.C. de $1,19 \times 1,40 \mathrm{~m}$, actualmente localizado en el Museo de las Termas de Diocleciano (Roma) y, uno de los más representativos de esta temática iconográfica, el hallado en las termas de Caracalla en 1824. Lo que quedó de este último fue transferido a Letrán por orden de Gregorio XVI y restaurado arbitrariamente para responder a las dimensiones del espacio que iba a cubrir. Gracias a los nombres inscritos y a los caracteres de la grafía, se piensa que el trabajo no es anterior al siglo IV d.C. La mayor parte de las figuras son atletas -quedan $20 \mathrm{fi}$ guras enteras y 26 bustos- que se ejercen en los alrededores de las termas. Los atletas se representan con diferentes insignias de victoria y algunos van armados para la lucha: púgiles con guantes, púgiles con corona, dos discóbolos con discos y un lanzador de lanzas con tres lanzas. Aquellos que se encuentran de pie se representan imberbes, mientras que algunos bustos son barbados y la expresión individual de ellos nos conduce a pensar que representan a veteranos célebres de la palestra. En otros cuadros decorativos de la composición general se realizan objetos propios de los combates o de la decoración de las palestras que también aparecen en nuestro ejemplo. Se trata de estrígilos, lekytos de aceite en vez de vasijas globulares, pesas de gimnasia, discos, coronas, palmas y vasos con dos asas contenedores de arena para frotar entre las manos de los atletas.

A pesar de todos estos ejemplos, es en las provincias donde encontramos una representación más completa de este tema iconográfico. Conservamos algunas escenas de este tipo en una pintura de la casa de Delos con luchadores desnudos, con lazos distintivos y representados junto a ánforas, palmas y la arena, participando en los juegos de las Compitalia (en Mon. Piot, XIV, 48, láms. 2-4). Sin embargo, los mosaicos siguen representando el mayor número de estas escenas. Ejemplo de ello son el mosaico d'Henchir Thina de Túnez con una pareja de luchadores de lucha libre dispues- tos en dos niveles y sin guantes (Gauckler y Merlín, 1910 y 1915, 23), el mosaico de Prato Rotatores cerca de S. Severa (Pyrgos), firmado por un tal Neilodorus, mosaista egipcio, en donde se representan guantes, palma y corona (en Jahreshefte, 1903, VI, 54), el de Villelaure y el de Aix en Provence, ambos en Gallia, con la representación de la lucha de Entellus y Darès (Eneida, V, 363) (Lafaye, 1909, 44 y 104; M illin, 1811, lám. 35).

Con respecto al último de los ejemplos gallos, pertenece a un pavimento de $8 \times 4 \mathrm{~m}$ que decora el triclinium de una rica vivienda cuyo cuadro central decora un gran tapiz. Sin embargo, el tema representado en éste no se corresponde con el carácter ocioso o anecdótico de Balazote, sino que forma parte de un repertorio de imágenes inspiradas en obras literarias conocidas en todas las provincias del Imperio $^{31} \mathrm{y}$, asimismo, un esquema decorativo que responde al repertorio predilecto galo-romano, sobre todo en el valle del Ródano. Sabemos que esta composición representa un ejemplo cuya expansión terminará por triunfar en el siglo III d.C., principalmente en ciudades próximas a ésta como Vienne y Lyon, de lo que se deduce que nos encontramos ante un artesano o taller de gran talento, que perfeccionó la reproducción de una imagen privilegiada para ofrecérsela a los clientes que la demandan.

En definitiva, podemos decir que como los baños estaban relacionados con los juegos de anfiteatro y las actividades deportivas de la palestra y eran un lugar de relajación después de los ejercicios, no es extraño encontrar este tipo de figuras (Mairi, 1958, 159-162).

En cuanto al análisis estilístico de su esquema decorativo, este tipo de imágenes se inscribe en la serie de pinturas con megalografías y posiblemente con arquitectura ficticia que aparecen en las provincias en la segunda mitad del siglo II d.C. (Belot, 1985), pero que también son muy frecuentes durante la segunda mitad del siglo III y comienzos del siglo IV d.C. (Khanoussi, 1988, 33-54). Es por ello que esta representación pueda corresponderse con la descripción de una de estas actividades a la manera de un cuadro agonístico y

\footnotetext{
${ }^{31}$ La imagen central de pugilato representa una escena procedente del canto " $V$ " de la Eneida de Virgilio que narra el combate del viejo Entellus contra el presumido Darès. De la escena sólo se muestra el resultado final del combate. Entellus porta una especie de guantes de boxeo hechos de tiras de cuero ya provistas de placas de plomo y Darès, vencido, presenta la frente sangrando por los golpes recibidos.
} 
de una escena de coronamiento tras la victo$\mathrm{ria}^{32}$. Esto puede ser confirmado por una información que nos ofrece Sidonio Apolinar a propósito de los baños de la villa de Auitacus, donde nos habla de los cuerpos pintados sobre los muros, de las posturas lascivas y equívocas de los púgiles y los atletas, así como de luchas verdaderas que son interrumpidas por la vara de los monitores o árbitros (Epitres: II, 2, 5-7, trad. A. Loyen). Con respecto a esto último, el personaje que se representa de perfil, mirando hacia la izquierda y con el dedo índice levantado, puede ser el mismo al que pertenezcan los fragmentos de túnica, un personaje vestido que parece romper el ritmo y lógica general de la escena, por lo que su presencia puede deberse a su cualidad de agon o árbitro. Este aspecto ayuda aún más, si cabe, a la definición de la escena ya que es posible que si esta figura se asimilase a un árbitro o entrenador, estaríamos ante una actividad deportiva con carácter de competición o una especie de arenga para la práctica del deporte. Otro dato importante que corrobora esta teoría es la utilización al lado de estas imágenes que hacen referencia a unas actividades deportivas que necesitan del uso de baños, de una serie abundante y homogénea de materiales mixtos propios de este tipo de estancias como puedan ser mosaicos parietales, conchas que simulan un ambiente acuático, etc. Está claro, por tanto, que los temas de palestra son preferenciales y que coexisten combinados con un tipo de decoración usada también para las fuentes y los ninfeos (Barbet, 1993, 11-12).

Este tipo de representaciones suele aparecer generalmente en termas de carácter privado (Le Glay, 1983, 266) como ésta de Balazote; sin embargo, conocemos muy pocos ejemplos en la península Itálica con los que podamos contrastar esta escena además de los anteriormente citados en pintura y en otro tipo de soportes. Únicamente mencionar los ejemplos de la pintura de las letrinas del Clivus Palatinus en Roma ${ }^{33}$ con la representación de escenas de gladiadores, las de Bolsena (Barbet, 1982) y las de las termas de la Casa del Menandro $(1,10,4)$ en Pompeya; el resto se concentran en las provincias, sobre todo en Gallia occidental. Uno de los más interesantes por su extensión y estado de conservación es el ejemplar de los muros norte, oeste y sur de las letrinas junto a las termas descubiertas en $\mathrm{S}$. Romain-en-Gal (Isère), construidas a finales del siglo II d.C. y abandonadas en la segunda mitad del siglo III d.C. (Leblanc, 1995, figs. $6,8,10-22,239-240$ ). Su decoración ilustra diversos aspectos de unos ejercicios físi- cos sobre un fondo arquitectónico de palestra: preparación, lanzamiento de disco, combate a manos desnudas, combate de pie o en el suelo, combate con guantes de boxeo, victoria y derrota, etc..., un total de dieciséis escenas conservadas. Concretamente de este último yacimiento contamos también con dos fragmentos que representan a un personaje mirando a la izquierda y con el brazo izquierdo alzado y otro personaje en dirección contraria con la zona de los muslos visible, posición similar a la nuestra (Leblanc, 1995, figs. 10-11, cuadros $1-2,245)$. Un personaje en una actitud muy parecida al que conservamos de perfil lo hallamos también en las termas de Vertault (Allag, 1998, fig. 17, 40). No obstante, al lado de estos temas deportivos donde los atletas luchan en la palestra, también se encuentran a menudo temas acuáticos y marinos como los de las termas del norte de Vaison-la-Romaine (Vaucluse) o de la rue des Farges (Rhône), aunque en nuestro caso no conservamos fragmentos representativos. En la mayoria de los casos, la elevación de estas estancias alcanza una altura de hasta $4 \mathrm{~m}$, puesto que de por sí los zócalos suelen ser bastante altos y, a continuación, en la zona media, la escala de los personajes es prácticamente la natural.

\section{1. 1. 2. 2.Vasos globulares}

Dos fragmentos informes de grandes y pequeñas dimensiones representan dos vasos globulares en color azul celeste que, probablemente, imitan recipientes de plata, o más propiamente de vidrio (Fernández, 2000, $\mathrm{n}^{\circ}$. cat: 6255-6256, lám. 223). Ambas vasijas representan el mismo tipo: panza globular, cuello estrecho y labio exvasado al exterior (Fig. 24-25). De una de ellas parten dos asas en color rojo, mientras que de la otra, además de éstas, también sobresalen una especie de cintas a ambos lados con forma indeterminada cuya función desconocemos, tal vez estrígilos para untar los aceites. El primero de los fragmentos se

\footnotetext{
${ }^{32}$ De todo el conjunto pictórico conservamos un fragmento de pequeñas dimensiones que podría representar una especie de corona y que correspondería a la pared sur de la habitación V. Ésta sería de color dorado con pequeñas incrustaciones circulares de color verde y rojo a intervalos regulares, tal vez, algún tipo de piedras preciosas. Asimismo, parece estar sobre la cabeza de algún personaje, puesto que conservamos restos del color castaño que se utiliza para la ejecución del cabello de los distintos atletas.

${ }^{33}$ Dato aportado por M. Fuchs en el seminario de pinturas murales antiguas de Chartres realizado en 1993. (n. 18 de O. Leblanc, 1995).
} 

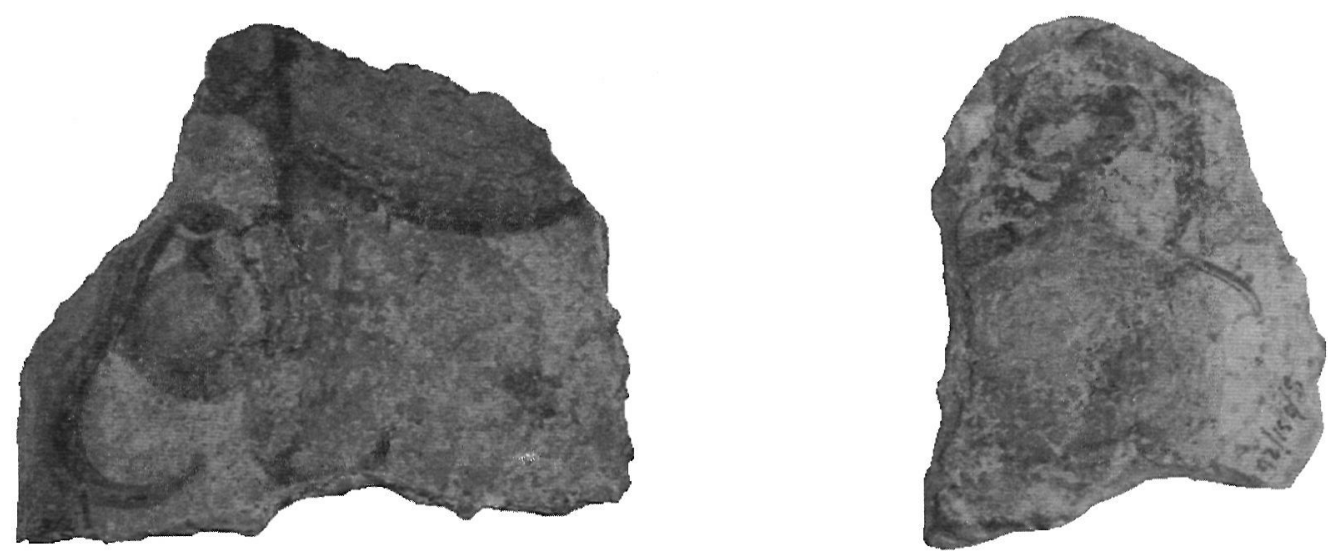

Figuras 24-25: Fragmentos con vasos globulares de vidrio contenedores de aceites (vitrina del Museo, foto: A. Fernández).

encuentra suspendido en el aire sobre el fondo blanco de toda la composición figurada, pero junto al costado de una figura masculina de la que únicamente disponemos de la parte inferior del tronco con la huella del ombligo y el brazo izquierdo que lo cruza.

Las representaciones de objetos diversos constituyen un apartado importante de la pintura romana. Algunos de ellos presentan una finalidad meramente decorativa, mientras que otros están impregnados de un gran simbolismo, como es el caso de los recipientes, los más ampliamente representados y que suelen emplazarse como motivos aislados o combinados con figuras diversas dentro de cuadros o libremente en el campo pictórico. Nuestros dos vasos forman parte de una escena con elementos decorativos aún más importantes como son las figuras humanas, por lo que pensamos que intervengan como objetos secundarios o de relleno en este tipo de composiciones mayores. No obstante, hemos de matizar también que su representación es lógica en un tema de ejercicios gimnásticos puesto que éstos a modo de ampollas contienen aceites con los que los atletas o bañistas impregnan sus cuerpos.

Los más bellos ejemplos de este tipo de vasos se encuentran en la habitación roja de la villa dei Misteri (Bastet y De Vos, 1979, 56-57), en la que todos muestran algunas características comunes tales como su realización mediante colores brillantes que imitan una vajilla de oro o plata -amarillento u ocre para imitar el dorado, azulado para imitar el vidrio y verde a veces para el bronce o cobre-, su ejecución fina y de pequeña talla. También en Pompeya conservamos ejemplos de vasos, pero en esta ocasión, dentro de cuadros de naturaleza muerta o en pequeños compartimentos, en medio de los paneles de la zona media o emplazados en la zona superior inmediatamente encima del registro medio. De entre ellos, podemos citar el cubiculum $C$ de la Casa dei Ceii $(I, 6,15)$, el triclinium 1 de la Casa dell'Orfeo (VI, 14, 20), donde aparecen mezclados con máscaras, y el mismo Edificio di Eumachia (VII, 9, 1). Por su parte, en las provincias contamos con un ejemplo muy parecido al nuestro en la ciudad de Bordeaux (Gironde), fechado sin embargo mucho antes, aproximadamente alrededor del 40 d.C. (Barbet, 1983, $2^{\mathrm{a}}$ parte, figs. 17-18, 139).

\section{1. 1. 2. 3. Inscripción pintada}

Un fragmento informe de tamaño medio $(15,3 \times 13,8 \mathrm{~cm})$ y de fondo blanco hallado en 1970 en la habitación III y actualmente en vitrina, presenta una película de costra salina sobre la superficie que impide ver en buenas condiciones la decoración. Ésta consiste en un nombre personal con letras capitales que se desarrolla en dos líneas aunque desconocemos si hay algunas más (Fernández, 2000, $n^{\circ}$. cat: 6259 , lám. 225). La primera y superior representa la letra $(\mathbf{H})$ añadida quizás como corrección gráfica del nombre escrito (Sanz y Abascal, 1993, 16), mientras que de la inferior únicamente conservamos (-TYCIVS) (Sanz y Abascal, 1993, 15-16) (Fig. 26). Estas letras

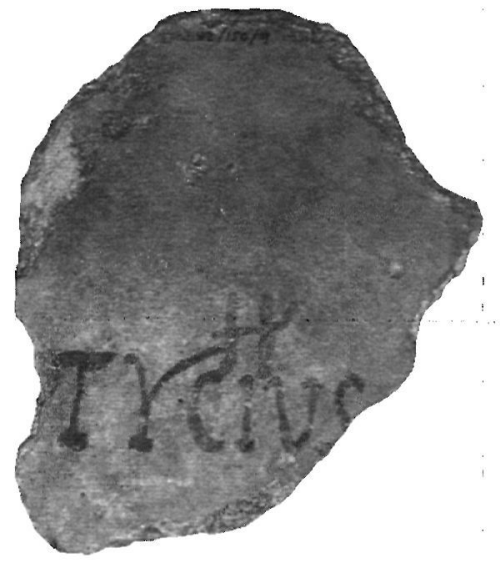

Figura 26: Fragmento con inscripción pintada en letra capital (vitrina del Museo, foto: A. Fernández). 


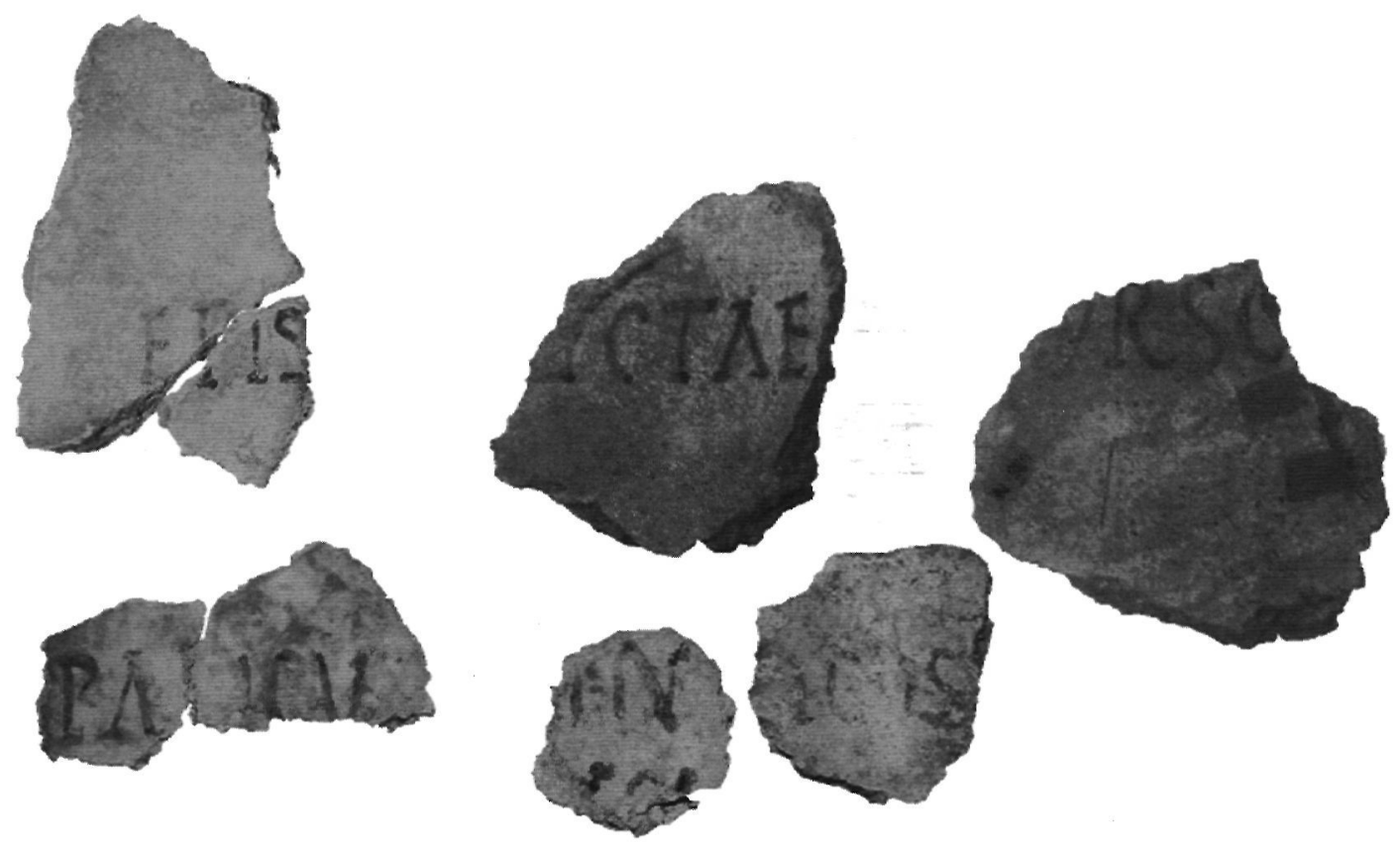

Figura 27: Fragmentos con diversas letras capitales pintadas (Foto: A. Fernández).

escritas en una actuaria bastante elegante están realizadas en color negro, posiblemente un pigmento obtenido del carbón vegetal, y su medida no es homogénea puesto que unas letras son más altas y grandes que otras; no obstante, podemos decir que su altura oscila entre 2 y $2,5 \mathrm{~cm}$ y su longitud es de $8 \mathrm{~cm}$. Antes de comenzar este texto parece observarse una mancha negruzca que debe corresponder a una letra de alguna palabra anterior o al inicio de ésta última y que actualmente ha desaparecido, tal vez (EU) TYCIVS.

Este escrito es una forma ya conocida dentro de las numerosas variantes que contienen el radical Eutych- entre los nombres griegos con grafía latina y aparece con frecuencia en inscripciones de Hispania en diferentes grafías y tanto en masculino como en femenino (Solin, 1971, n.7). El único testimonio peninsular lo encontramos también en Castilla La Mancha, concretamente en Castillejo (EE8, Cuenca, 189).

De la habitación $V$ también proceden varios fragmentos con la representación de epígrafes incompletos y pintados también en negro sobre el fondo blanco del enlucido (Fig. 27). Una de las piezas, informe y de pequeñas dimensiones, conserva algunas letras en capital de $2,8 \mathrm{~cm}$ de altura (-YCTAE) ${ }^{34}$. Otro de los fragmentos, también informe y de pequeñas dimensiones, prensenta algunas letras en capital de $2,6 \mathrm{~cm}$ de altura (-EROI) ${ }^{35}$, pero en esta ocasión, sabemos que corresponden a la pa- red este de la estancia. Una pieza informe y de medianas dimensiones conserva el tercio inferior de unas letras capitales que no alcanzamos a distinguir y que irían ubicadas en la pared norte ${ }^{36}$. A la pared este corresponden al menos cinco fragmentos informes y de muy pequeñas dimensiones que contienen varias letras capitales pero de las que únicamente podemos diferenciar algunas (-YCT-, N-, EPIS-, -RSO, S- y -U-) $)^{37}$. El último de los fragmentos, informe y de pequeñas dimensiones, también corresponde a esta pared y conserva únicamente tres letras capitales, (-LVS) de 2,6-2,8 cm de altura $^{38}$. De todos ellos, la única palabra que

\footnotetext{
${ }^{34}$ Ficha técnica: Campaña de 1972, habitación E (631, sin referencia de pared). $\mathrm{N}^{\circ}$ inventario provisional: E/31(a). Grosor: $5,2 \mathrm{~cm}$ de grosor total conservado sin reverso en espiga.

${ }^{35}$ Ficha técnica: Campaña de 1972, habitación E, cuadrícula E6, nivel Ilb (632, pared este). $\mathrm{N}^{\circ}$ inventario provisional: $\mathrm{E} /$ 31 (b). Grosor: $1^{\text {a }}$ capa: $0,5 \mathrm{~cm} ; 2,7 \mathrm{~cm}$ de grosor conservado sin reverso en espiga.

${ }^{36}$ Ficha técnica: Campaña de 1972, habitación E, cuadrícula $E 6$, nivel IIb $\left(633,889\right.$ pared norte, ángulo oeste). $\mathrm{N}^{\circ}$ inventario provisional: E/31(c). Grosor: $3,2 \mathrm{~cm}$ de grosor conservado con reverso plano.

${ }^{37}$ Ficha técnica: Campaña de 1972, habitación E, cuadrícula E6, nivel Ilb $(634-638$, pared este, 654, 668). No inventario provisional: $E / 31$ (d-h). Grosor: $2,9 \mathrm{~cm}$ de grosor conservado con reverso plano.

${ }^{38}$ Ficha técnica: Campaña de 1972, habitación E, cuadrícula $\mathrm{E} 6$, nivel Ilb (639, pared este, ángulo norte). $\mathrm{N}^{0}$ inventario provisional: E/31(i). Grosor: $2,4 \mathrm{~cm}$ de grosor conservado con reverso plano.
} 
creemos que está completa corresponde a tres fragmentos que, unidos, forman (PALICUS). Tal vez, estas letras corresponden a palabras tales como EPISTOLA, PYCTAE, CORSO, PALICUS, ...

En primer lugar, hemos de distinguir entre la inscripción que conservamos que parece de una escritura relativamente cuidada, por lo que probablemente su destino es permanente, y las inscripciones que tienen un carácter espontáneo y pueden haber sido realizadas por cualquier visitante ocasional. Por otra parte, hemos de destacar el uso del color negro sobre fondo blanco, práctica que está bien atestiguada: in tabula, in albo, atramento scriptos ... habeto (C/L, I, 198, 14: ... sobre un cuadro de fondo blanco, que los presenta escritos a tinta ...). Los romanos disponen además de una tinta negra excelente procedente de la descomposición orgánica -carbón-, que les permite escribir legiblemente sobre varios tipos de soporte como puede ser la cerámica o los enlucidos pintados. Asimismo, si este soporte no es frágil, esta tinta resiste normalmente la acción del agua.

Las inscripciones pintadas sobre enlucido pueden tener destinos diversos, sin embargo, las representadas con más frecuencia suelen ser nombres o explicationes (Rebiffat, 1995, 26). Las más comunes corresponden a escenas pintorescas, una serie particular en la cual se pueden incluir las actividades comerciales y lúdicas, en muchas ocasiones con carácter de anuncio publicitario (Allag, 1985, 148-149), y a través de las cuales podemos conocer algo más sobre el destino o la función del lugar de origen y los ambientes en los que suelen aparecer, como por ejemplo salas de recreo, triclinia, etc. Cuando están asociadas a la decoración pintada de una habitación, generalmente son leyendas que mencionan el nombre de los héroes de una escena o hacen comentarios sobre esta última, como puede ser nuestro caso. De esta manera, nuestra inscripción corresponde al grupo de inscripciones que acompañan a las escenas mitológicas, los espectáculos, carreras de caballos, combates de gladiadores y venationes (Dumasy, 1983, 199219), y relatan estas grandes epopeyas, gestos mitológicos, grandes hechos, victorias, sacrificios o triunfos pintados en los cuadros o en las paredes de los edificios públicos, de las casas o de las tumbas; como consecuencia, la voluntad narrativa de la escena pintada queda patente con esta inscripción pintada.

En lo que respecta a la cronología, podemos decir que esta costumbre de reseñar así las imágenes para que ninguno las ignore, es antigua (Quintiliano: I, 4, 16). Si tenemos en consideración que el número de inscripciones lapidarias crece enormemente en el principado de Augusto y la técnica epigráfica se modifica a favor de la mentalidad de las inscripciones o de la propaganda, que era una garantia contra el olvido ${ }^{39}$, es lógico pensar que suceda lo mismo con las inscripciones pintadas, que por otra parte, también son el único medio de escritura en las paredes (Rebuffat, 1995, 29). Desconocemos si el uso de los colores pudo estar codificado y tuvo en consecuencia un significado o cronología precisas; no obstante, sabemos que Quintiliano hace una distinción entre el "Edicto de Pretor" escrito en negro sobre un album -las leyes civiles caracterizadas por sus rúbricas- y otros ejemplos importantes (Quintiliano: XII, 3, 11). En nuestro caso, los fragmentos que conservamos con al menos dos líneas, presentan trazas de letras capitales rectas pero de desigual altura que, sin embargo, por la forma de sus caracteres nos ayudan a precisar una datación posiblemente bajo imperial.

En Roma encontramos escenas como las observadas aqui y cuya datación puede ser similar a la de las termas de Balazote, es decir siglos III-IV d.C. (Wirth, 1968, láms. 29-30, 2931). Fuera de la península Itálica, elementos de escena legendaria con inscripciones pintadas las hay en Saintes (Charentes-Maritimes) (Allag, 1985, 141-152) y son comparables a las informaciones pintadas en la fachada de Pompeya que muestran artesanos y comerciantes en el trabajo. Otros ejemplos a los que podemos aludir son los de la pequeña inscripción de un género particular -figura portadora de un rollo de papiro al lado de un genio- que ofrece la pieza K de la Casa con Pórticos en Narbona datada en el siglo II d.C. (Sabrié, 1995, 69) y el de la inscripción pintada combinada con combates de gladiadores de La Croisille-sur-Briance (Haute-Vienne) (Dumasy-Mathieu, 1991, 192) que corresponde, posiblemente, a una inscripción conmemorativa.

\section{1. 2. Habitaciones VI, VII y VIII}

\section{1. 2. 1. Zona media o zona superior}

\section{1. 2. 1. 1. Florones}

Procedentes de las habitaciones VI, VII y VIII cuya funcionalidad es posiblemente la de frigidarium, conservamos un gran número de fragmentos informes y de pequeñas dimensio-

\footnotetext{
39 Horacio, Oda: 4, 14. "Quae cura ... Auguste, Virtutes in auum per titulos memoresque fastus aeternet...".
} 

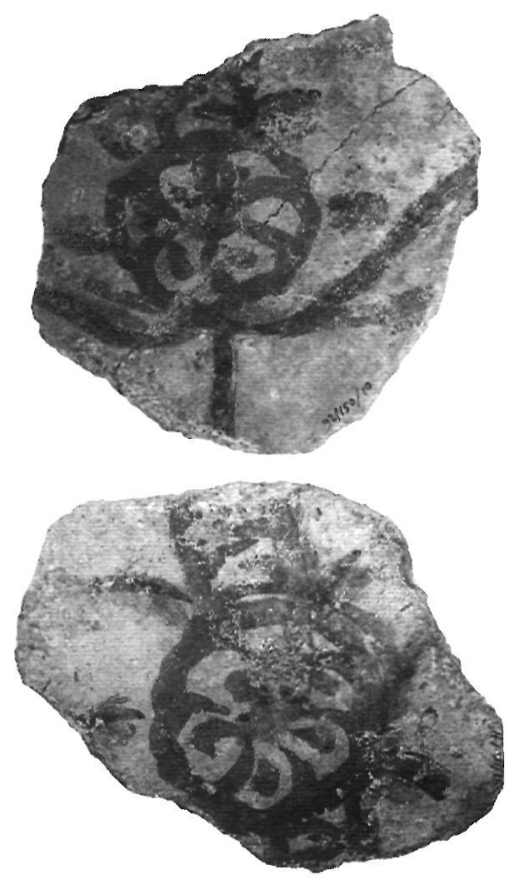

Figura 28: Fragmentos con la representación de florones esquematizados pendientes de guirnaldas (Foto: A. Fernández)

nes que representan florones muy esquematizados y que a su vez penden de guirnaldas (Fig. 28). El color rojo se utiliza para marcar el contorno exterior de éstos y el de sus propios pétalos cuyo interior se deja en el color blanco de fondo (Fernández, 2000, $\mathrm{n}^{\circ}$. cat: 6257-6248, lám. 224). A su alrededor, se suceden una serie de hojas muy estilizadas en color verde oscuro y claro. Estas flores presentan en sus extremos unas bandas rojas a modo de guirnaldas de las que desconocemos su función pero que posiblemente sirvieran de unión de una flor con otra.

Encontramos flores de este tipo de las que parten sendas ramas vegetales, incrustadas en cuadrados que decoran la bóveda del interior del Columbario de Vía Taranto en Roma (Borda, 1958, 65). Este tipo de decoración vegetal y floral se extiende sobre el mismo fondo blanco y cálido de las paredes y de la bóveda, con una entonación clara y luminosa que ofrece un sentido de liviandad. Sus comienzos se localizan en época claudio-neroniana, coincidiendo con el sistema en red que será tan común en el siglo II d.C. En definitiva, se trata de una pintura liviana y miniaturista que es especialmente adecuada para paredes y bóvedas de pequeños ambientes así como para columbarios en los que predomina la decoración floral adaptada por su simbolismo al mundo funerario, aunque este último no sea nuestro caso.

\section{1. 3. Habitación $X$}

\section{1. 3. 1. Imitación de mármol moteado}

En primer lugar contamos con un fragmento proveniente de las vitrinas del museo (Fernández, 2000, $n^{\circ}$ cat: 6244 , lám. 220 ), que contiene un esquema semejante al que conservamos en treinta y cinco fragmentos más localizados en los fondos del mismo ${ }^{40}$. Se trata de treinta y seis fragmentos informes de medianas y pequeñas dimensiones de pintura mural con imitación marmórea. Sobre un fondo de color rojo se representa una gran cantidad de motas de forma ovoide y circular -blancas y amarillas- de gran tamaño. Dicha superficie no representa un campo de grandes dimensiones, sino que, en ocasiones, se trata de una banda roja que quizás represente un motivo o elemento curvo, y todo ello sobre un fondo blanco en el que se cruzan bandas negras y amarillas de 0,9 y $0,7 \mathrm{~cm}$ de anchura respectivamente. Asimismo, dos de las piezas presentan un ángulo de $270^{\circ}$ propio de una abertura, posiblemente un vano de acceso a la estancia a la que pertenecen (Fig. 29).

De este conjunto, destacan seis fragmentos que conservan la imitación de este mismo tipo marmóreo pero atravesado por tres bandas negras -las dos laterales más finas de 0,5 $\mathrm{cm}$ de anchura y la central, más gruesa, de 1,1/ $1,2 \mathrm{~cm}$ de anchura-. La ejecución de estos motivos lineales con una pincelada bastante diluida nos permite observar el fondo rojo y las motas blancas. De la misma manera, observamos que la calidad ejecutiva de éstas no es muy buena, pues la capa superficial no está bien alisada y queda muy pastosa, lo que hace que aparezcan con un poco de volumen.

Estas últimas piezas descritas podrían corresponder al encuadramiento interior y ex-

\footnotetext{
40 Ficha técnica: Caja 50. 1/9 (774-809) sin referencia de ninguna clase. $\mathrm{N}^{\circ}$ inventario provisional: $36\left(\mathrm{a}-\mathrm{h}^{\mathrm{l}}\right)$. Grosor: $1^{\mathrm{a}}$ capa: $0,3 \mathrm{~cm}$ de mortero blanco, una capa muy bien definida en todos los fragmentos; $2^{a}$ capa: $1,3 \mathrm{~cm}$ de mortero gris; $3^{a}$ capa: $1,6 \mathrm{~cm}$ de mortero beige; $4^{\mathrm{a}}$ capa: $0,7-1 \mathrm{~cm}$ de mortero blanco. En total, se trata de fragmentos de $5,2-6,3 \mathrm{~cm}$ de grosor conservado sin reverso claro, pero con un mortero diferente al visto para el resto de fragmentos correspondientes al resto de composiciones de las termas. Esta caja conserva también dos fragmentos con partes indeterminadas de un cuerpo masculino -tal vez rodillas-, asi como un fragmento rojo atravesado por una banda blanca de $0,7-0,8 \mathrm{~cm}$ de anchura; no obstante desconocemos la habitación a la que pertenece por lo que no podemos afirmar que ambas composiciones pertenezcan a la misma estancia, pero sí que una de ellas corresponde a la $X$.
} 


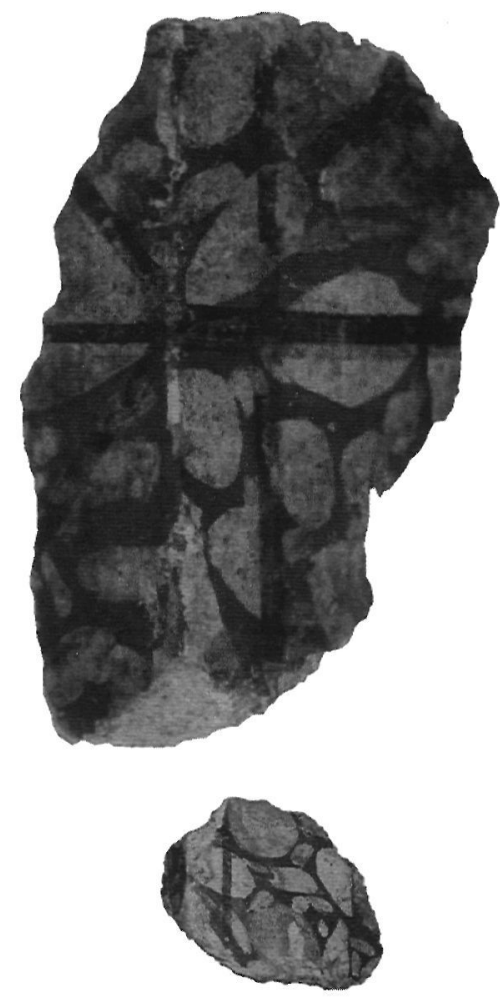

Figura 29: Fragmentos con imitación de mármol moteado (Foto: A. Fernández).

terior de una lastra marmórea emplazada posiblemente en una zona elevada del registro medio de la pared. Aunque desconocemos si esta ubicación propuesta es correcta al no conservar ninguno de estos fragmentos in situ, el tamaño y grosor conservado de los mismos podrían corroborar esta posición en la pared.

El tipo de mármol imitado en estas piezas no es muy representado en la pintura antigua, pero podemos decir que se asemeja formalmente al mármol pórfido serpentino que, sobre fondo negro, representa una especie de motas ovoides en forma de granitos de arroz de menor tamaño- en color verde. Este conjunto es también el único que difiere del resto de la composición, y tal vez sea porque pertenece a otra estancia, a la habitación $X$ o trícora, denominada así por Fernández Castro, y con una función totalmente diferente. A falta de otros datos, y si analizamos el tipo decorativo, podría representar también la imitación de un tipo de mármol correspondiente a un alabastro florido, como el ilustrado por $M$. de Vos con fondo rojo y vetas amarillas, blancas y ocres para una casa pompeyana (De Vos, 1977, lám. XXXII.25, 33); no obstante, hemos de matizar que más que vetas parecen motas de gran tamaño.
Al igual que observamos en la imitación de placas marmóreas, algunas piezas presentan un fino trazo y un filete negro que sirven de encuadramiento interior de la lastra, pero a diferencia de otros ejemplares, el de la vitrina deja la representación de estos listeles para el final de la decoración, localizándose encima de la composición de fondo. Este tipo florido, también mencionado por Pernice, se combina con una especie de figuraciones de paisajes marinos con desarrollo coralino, tal y como podemos observarlo en la pared este del vestíbulo de la Casa del Fauno (VI, 12, 2) (De Vos, 1977, láms. 33-34, figs. 26-28 y 30) y en las Casas VI, 16, 19 y VII, 6, 36 también en Pompeya, algo que podría corresponderse con la propia composición que pudiera existir en alguna de las salas próximas a estas termas de Balazote.

\section{RESTITUCIÓN E INTERPRETACIÓN DEL CONJUNTO (FIG. 30)}

Ante las escenas decorativas y las inscripciones de las habitaciones III, $\mathrm{V}$ y XII de las termas de Balazote, todas ellas incompletas, podríamos ofrecer una multiplicidad de propuestas. Nos decantamos por una de ellas, la de una escena de palestra de carácter posiblemente conmemorativo debido a la presencia de los mensajes, tanto pictóricos como textuales (véanse Fig. 26-27), correspondientes a una serie de estancias relacionadas con el conjunto termal al que pertenecen. Si en Grecia los atletas ilustraban las diferentes fases de la actividad atlética del entrenamiento en los gimnasios donde el ejercicio físico ampliaba las disciplinas del intelecto, muchos autores comparten la opinión de que en época imperial romana los ejercicios físicos eran muy importantes y siempre debían estar relacionados con la existencia de una palestra. Con respecto a la intención narrativa de las escenas, ésta no puede negarse, aunque desconocemos si se trata de juegos financiados pues las inscripciones están incompletas y lo único que podemos decir de ellas es que tienen como finalidad asegurar una escena no totalmente ficticia en el recuerdo, además de simbolizar una invitación a la práctica de un deporte para el desarrollo físico del cuerpo.

Estas pinturas están en perfecta adecuación con su contexto termal y deben relacionarse con una palestra que, en la actualidad, todavía no se conoce. La duda más acuciante viene a la hora de ubicar dicha decoración, pues 

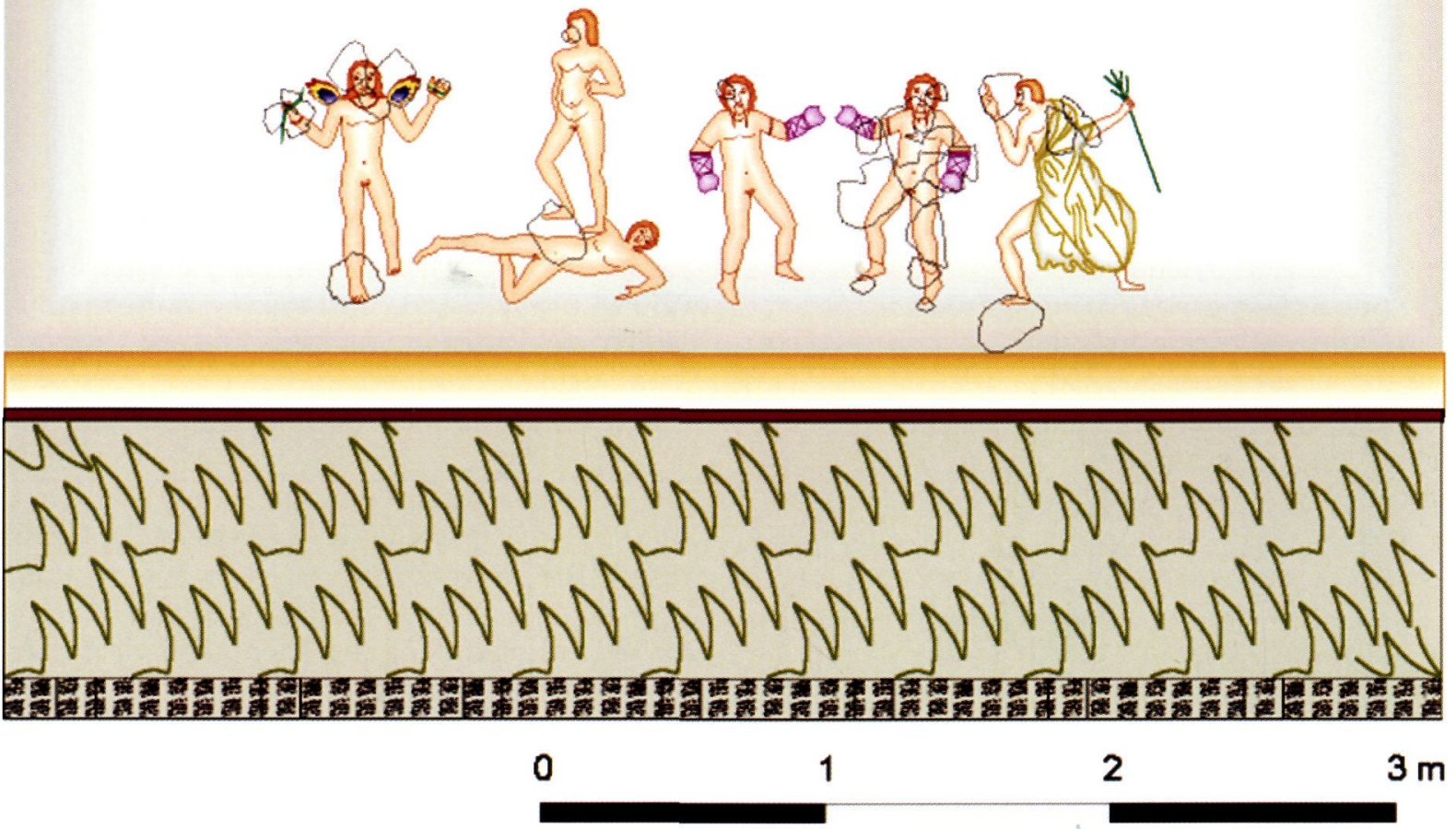

Figura 30: Restitución hipotética de la escena figurada a modo de friso corrido (Dibujo: A. Fernández).

se trata de una escena muy homogénea que pudo pertenecer a cualquiera de las estancias anteriormente mencionadas, pero que sin embargo, en el momento de derrumbe se dispersó entre las tres por la cercania que había entre ellas -la $V$ es un corredor que da acceso a la III y XII que podrían corresponder a dos unctaria-.

A veces es posible identificar lugares y funciones, pero la dificultad principal subsiste cuando el local cambia de función. En el caso de las habitaciones mencionadas, desde su construcción hasta su abandono no observamos ningún tipo de reforma constructiva a excepción del hallazgo de una primera fase pictórica de la que desconocemos su esquema y sistema decorativo. Debido a ello, a la hora de interpretar este conjunto, únicamente hemos de basarnos en la relación existente entre la decoración parietal de las estancias y el uso de éstas como edificio termal, interesante cuestión cuya respuesta es también difícil puesto que los dos conceptos, decoración parietal y función, son caracteres siempre complejos. En primer lugar, hemos de tener en cuenta que cuando hablamos de decoración parietal ésta no ha de corresponder solamente a la estructura, color, elementos y motivos representados, sino también a conceptos como datación, efecto, intención y significado. En segundo lugar, y con respecto a la función, hemos de tener claras dos ideas distintas: una implica el uso específico de estancias, bien sean tablina, triclinia, etc, mientras que la otra indica la relación de éstas con el edificio entendido como un todo.

En cuanto a la decoración que mostramos, a falta de esquemas estrictamente completos, nos basamos en una búsqueda más profunda en el resto de los programas de decoración integrados con la pintura, sobre todo estu$\cos$ y mosaicos ${ }^{41}$, donde las escenas de palestra también se representan a menudo. Gracias a esto, y a pesar del riesgo de definir un tipo de función de las habitaciones desde el único punto de vista de la decoración, podemos observar la utilización de temas precisos para lu-

41 Destacan los mosaicos de Acheloos de Salzburgo (Austria); de los atletas vencedores de Vienne (Francia) y de la Casa del Casegiatto dei lottatori de Ostia (Italia). En la provincia africana conservamos los de Thuburbo Majus y el de Thyna, para los cuales véase Fradier (1986). 
gares precisos como ocurre en las termas privadas de la villa de Balazote. La estructura de las termas y la decoración ornamental de una de sus estancias conduce a pensar en la existencia de un rico propietario, tal vez un tal Caelius Proculus, que aparece en una inscripción y que al igual que en las termas públicas de la ciudad, asocia la palestra al balneus y decora sus salas de baño con mosaicos y enlucidos pintados con un valor iconográfico relacionado con la función de las salas de las que se compone. A pesar de la fragmentación, las piezas aluden a escenas en las cuales unos personajes masculinos, ciertamente jóvenes, se preparan para la realización de actividades físico-deportivas, bien sean juegos atléticos -lanzamiento de disco- o combates de boxeo. Esta actividad es confirmada además por la presencia de los vasitos globulares que contienen los ungüentos $o$ aceites que los propios deportistas untan sobre su cuerpo mediante los estrígilos y que también aparecen en el mosaico de las sandalias -siglos III-IV d.C- (Blázquez et alii, 1989) y por la presencia de un personaje de perfil con uno de sus dedos levantado que indica que la escena posiblemente esté bajo su atenta mirada, la de un dignatario que ejerce la función de árbitro, entrenador o maestro.

En definitiva, en más de un edificio termal como en nuestro caso, que poseía siempre su palestra y vasto patio donde los bañistas se entrenaban en la lucha u otros menesteres, como por ejemplo el pavimento de luchadores de las termas de Gigthis o de Bou-Ghrara, entre otros ya mencionados anteriormente, los jóvenes inscritos sobre los papeles de la iuventus realizaban sus entrenamientos regulares en palestras especiales como la schola de los Jóvenes en Mactar o la palestra de los Petronii en Thuburbo Majus (Ennaïfer, 1973, lám. 21 b y c, 59) y practicaban igualmente la carrera y el boxeo. Gracias a todos estos datos y sin entrar en el debate de la representación iconográfica de una schola (Carcopino, 1939, 293 y ss.), confirmamos la importancia del haIlazgo, un amplio complejo termal decorado como corresponde a un lugar de esta categoría, propia de una villa de tipo aúlico como ya señalaran en su día J.G. Gorges (Gorges, 1979, 132) o R. Sanz Gamo (Sanz, 1995, 355-356) y el interés del propietario por estos concursos atléticos entre finales del siglo II d.C. y a lo largo del siglo III d.C., momento de construcción de las termas, siguiendo una moda muy difundida por todo el Imperio (Plinio el Joven, Cartas: IV-22).
Si nos remontamos en el tiempo, los juegos en Grecia ilustran las diferentes fases de la actividad atlética del entrenamiento en los gimnasios, donde el ejercicio físico ampliaba las disciplinas del intelecto, es decir, el premio de los vencedores después de la competición. Se sabe que el atleta vencedor era coronado por una Niké o Victoria alada que simbolizaba la victoria momentánea y que en cualquier momento estaba dispuesta a dirigirse sobre la cabeza de otro vencedor. En nuestro caso, esa figura podría estar representada por el personaje masculino alado, tal vez un erote (véase Fig. 22). Tras esto, llegaba el momento de la consagración en la que al atleta se le dedicaba una estatua de bellas proporciones expuesta en el ágora de los ciudadanos y realizada por encargo a los artesanos más destacados.

En líneas generales, el deporte en la antigua Grecia era legado a un antiguo ideal de virtud, necesario para la formación del ciudadano como soldado. El atleta era entrenado para ofrecer lo mejor, no por el espíritu de competición con otros sino para demostrar la propia virtud o areté. El personaje alado, independientemente de su sexualidad, era el símbolo fugaz de la preparación del individuo y de su victoria personal sobre límites propios, una afirmación de la disciplina propia y de su propio empeño. Debido a este significado individual de las competiciones deportivas, en Grecia no existe el deporte en grupo, sino sólo la competición individual. Este ideal heroico de perfección se encuentra ya en épocas anteriores, de manera que las principales manifestaciones deportivas en Grecia son los juegos panhelénicos y las fiestas en honor a Atenea donde se practicaban ya algunos de los ejercicios que vemos representados en estas pinturas como el pugilato, la lucha o el lanzamiento de disco, además de otros como la carrera, el lanzamiento de jabalina y la carrera de carros.

Por su parte, en el mundo romano, el espíritu de los juegos es bien distinto. Aquí, mientras los juegos tenían un carácter espectacular y, por tanto, las disciplinas preferidas eran las carreras de carros en el Circo y los juegos gladiatorios en la arena, los "juegos a la griega" tardaron en arraigarse. Los atletas estaban mucho mejor considerados que otros profesionales aunque seguían siendo reclutados entre las clases menos elevadas. Sus representaciones eran rudas al contrario que las de las figuras atléticas griegas que resultaban mucho más elegantes, lo que demuestra nuevamente que en el mundo romano las mani- 
festaciones deportivas tenían un carácter más de ocio o divertimento, como nos transmiten los escritores latinos. Asimismo, la organización de estos juegos era un modo para ganarse el favor del pueblo y con el tiempo resultó ser un instrumento de propaganda política tanto para el Senado como para los emperadores.

Pero lo que más nos interesa es cómo la lucha y el pugilato entran dentro de lo que en Roma se denominaron como las disciplinas que constituían el atletismo pesado junto al pancration $^{42}$. En estas disciplinas no existían categorías de peso, por tanto los combates entre los atletas eran sorteados por la presencia de los presidentes de las competiciones con el siguiente sistema: el destino era confirmado por letras duplicadas del alfabeto. Aquellos que extraían la misma letra competían juntos; mientras que, en el caso en el que los participantes fueran impares, al que le tocaba la letra dispar pasaba al turno sucesivo con la ventaja de competir todavia más descansado con un contrincante o atleta ya fatigado de un primer combate.

En nuestras pinturas podemos observar algunas de las especialidades de la lucha, como por ejemplo la que se practicaba durante los entrenamientos y el encuentro terminaba sólo cuando uno de los dos combatientes se declaraba vencido (véase Fig. 7). Todos estos encuentros de lucha se desenvolvían generalmente de pie con los brazos avanzados y durante éstos estaba expresamente prohibido el uso de guantes y zapatos, mientras que se admitian las zancadillas y todas las presiones o golpes sobre la parte superior del cuerpo. Todos estos detalles y además, las descripciones de los luchadores ideales las podemos encontrar en la obra de Filostrato de los siglos II y III d.C., por tanto, bastante próxima a la datación de estas escenas ${ }^{43}$

Con respecto al pugilato, también presente en estas pinturas, sabemos que era una disciplina deportiva con reglas y técnicas bien estudiadas, así como que durante el encuentro no se preveían las pausas debido a lo cual se continuaba hacia delante hasta que uno de los combatientes caía fuera de combate o alzaba el brazo en acto de rendición. Todo ello era supervisado por un árbitro como posiblemente sea uno de nuestros personajes que aparece representado alzando un dedo (véase Fig. 4 y 14). También sabemos que el blanco preferido de los combatientes era la cabeza como demuestra la imagen del único púgil que tenemos casi completo y que sangra por la nariz (véase Fig. 11), pero de lo que carecemos es de la representación de las orejeras y del cue- ro atado bajo el mentón que se usaban como protección, de lo que podemos deducir que quizás estemos ante unos entrenamientos más que ante un combate propiamente dicho. Éstos resultaban mortales y normalmente los púgiles acababan totalmente desfigurados. Se combatía con guantes particulares que se apretaban mediante correas entrelazadas que dejaban libres el dedo pulgar y giraban en torno a los otros dedos de la mano, cubrían la muñeca e incluso el antebrazo (véase Fig. 11 y 21). Además, los "guantes" romanos estaban dotados también de grandes clavos, cuyos efectos devastadores pueden ser fácilmente intuidos por una de las imágenes representadas en estas escenas (véase Fig. 20).

\section{A MODO DE CONCLUSIÓN}

En lo que respecta al tema iconográfico en la decoración de estas termas, podemos decir que se trata de un juego o distracción en la actividad principal de éstas, por otra parte, una de las distracciones más antiguas del hombre (Ennaïfer, 1973, 53-54). En cuanto a esto último, en la civilización griega pero sobre todo en la romana, los ciudadanos pensaban que las autoridades públicas debian proporcionarles las ocasiones y los medios oportunos para diver-

\footnotetext{
${ }^{42}$ El pancration deriva su denominación de los pancrates u omnipotentes y era un conjunto de lucha y pugilato, donde los atletas competian con sus manos desnudas en un combate en donde todo estaba permitido: botas, uso de los dedos rectos, torsiones de las articulaciones, roturas de huesos, intentos de estrangulamiento, etc... además de morder y arañar, como narra Pausanias.

43 Filostrato, De la Ginnastica: El luchador ideal será más alto de lo normal, estará bien formado y tendrá el cuello alto pero no unido a los hombros... Del resto, de las estatuas de Hércules se puede comprender cuan son más bellos y perfectos los cuellos libres y no encajados en los hombros. Debe tener pues el cuello recto como un caballo bello y altanero, y la base del cuello ha de ser equidistante entre las dos clavículas. Hombros simétricos y bien plantados confieren al aspirante luchador imposición, nobleza de aspecto, fuerza y lo convierten en más apto para la lucha. Este filósofo también comenta que: Un buen abrazo es de buen auspicio en la lucha, cuando tenga amplias venas que, originándose en la nuca y en el cuello, se difundan a través de los hombros finalizando en las manos y corriendo por brazos $y$ cúbitos... Los mejores torax son aquellos claramente prominentes...; y los atletas que poseen todo esto son bellos, fuertes, sanos, ardientes y reflexivos al mismo tiempo...; bellas son las espaldas rectas, pero atléticamente son mejores las que son un poco curvas, más adaptadas a los movimientos que requiere la lucha, que se basan sobre contorsiones y pliegues -lucha cuerpo a cuerpo-pero conseguirá mayor éxito aquel que en la primera fase sólo luche con las manos.
} 
tirse, pero como observamos en este ejemplo, en ámbitos privados también parece que sucedía esto.

Con respecto a estas representaciones, se trata de atletas ejercitándose en distintas actividades físicas y deportivas dentro de un contexto romano; sin embargo, estos ejercicios se remontan mucho antes, concretamente a la Grecia del siglo VIII a.C. Los griegos atribuían a la mayor parte de los juegos un origen muy antiguo y mitológico, por tanto, los ponían en estrecha relación con la religión ${ }^{44}$. Pero lejos de su carácter religioso, los juegos eran una de las instituciones más antiguas e importantes de la antigua Grecia, con ocasión de los cuales cesaban las posibles hostilidades entre las distintas ciudades griegas. Se trataba de juegos de carácter público y gratuito y estaban repartidos en tres categorías: juegos ecuestres, gimnásticos y concursos de música, canto y danza. Con el paso del tiempo, y tras la muerte de Alejandro Magno, los juegos se expandieron fuera de la frontera griega hasta donde había penetrado la civilización helenística: Asia Menor, Siria o Egipto, perdiendo poco a poco su carácter religioso. A partir de entonces, los juegos se celebraron en honor a nuevos jefes y no en honor de los dioses o para apaciguar la cólera de éstos.

Por su parte, los romanos tomaron sus espectáculos de la civilización etrusca: carreras de caballos y carros, combates de gladiadores, juegos escénicos (mimos, música, etc...). Estas actividades tuvieron su apogeo principalmente durante los primeros cuatro siglos del Imperio. Esta pasión por los juegos se expandió desde Roma y a través de Italia, a todas las provincias occidentales del Imperio, sobre todo a África, donde fueron numerosos los circos, anfiteatros y teatros que estuvieron en uso o fueron reparados. Estas distracciones se extendian durante largas jornadas sobre los graderíos, a veces durante la noche, aclamando a los luchadores con antorchas y lámparas. A diferencia del mundo griego, en época imperial romana, el contenido religioso de los juegos se había perdido, pero no había desaparecido por completo. De la misma manera, el carácter educativo de éstos, tal como lo habian concebido anteriormente los griegos "mens sana in corpore sano", estaba probablemente más en vigor en África que en la propia Roma. A este respecto, hay razones para pensar que los habitantes de África de esta época eran más deportistas que los de otras provincias del Imperio, ya que las inscripciones que proceden de allí son casi las únicas en mencionar, entre las fiestas públicas, las de gimnasia -cuarenta menciones por tres de otras regiones- (Picard, 1959, 401).

En cuanto al sistema decorativo al que corresponde este conjunto de las termas de Balazote, se desarrolla en época bajo-imperial, probablemente en el siglo III d.C., pudiendo relacionarse con las decoraciones de los edificios romanos que comienzan a realizarse a partir de la primera mitad de este siglo (Borda, 1958, 118-120). En la pintura decorativa de esta época se observa un claro abandono de la fórmula y de los motivos tradicionales, advirtiéndose una importante predilección por 10 oblicuo y la asimetría, por la forma geométrica, por una tendencia ilusionista y simplificada que se expresa por una absoluta predilección por el elemento lineal. Esta tendencia ilusionista vuelve a su máximo potencial hacia mediados del siglo III d.C., teniendo como máximo exponente el ambiente de acceso a las catacumbas de S. Sebastiano, aunque decoraciones afines también pueden observarse en el edificio de Vía del Imperio, en una casa bajo la Vía de Diana y en un sepulcro cerca de Porta Romana en Ostia, así como en una taberna a los pies del Campidoglio (Borda, 1958, 128). En este sistema decorativo la arquitectura se reduce a escasos elementos y se confina principalmente a espacios intermedios. En definitiva, se trata de nuevos valores de la civilización romana que representan la expresión de una nueva posición espiritual con influjos orientales, de naturaleza simbólica y trascendental. Todo esto pudo ser consecuencia de factores de índole histórica como la crisis del Imperio debida a causas religiosas y sociales o a la confirmación del Cristianismo, del Judaísmo y de la creencia sincretista que parecen provocar en la vida romana una profunda mutación.

Con respecto a esto último, contamos con numerosos ejemplos de este nuevo esquema decorativo, tanto en ambientes domésticos o de carácter privado como en ambientes funerarios, por tanto, una demostración de la absoluta equivalencia entre las formas de la decoración habitacional y sepulcral.

\author{
Profa. Alicia Fernández Díaz \\ Area de Arqueología \\ Dpto. de Prehistoria, Arqueología, $H^{a}$ Antigua \\ Facultad de Letras \\ c/ Santo Cristo, 1 \\ 30001 Murcia \\ aliciafd@um.es
}

44 Los olímpicos, por ejemplo, estaban en relación con Heracles, mientras que los /sthmicos con Poseidón. 


\section{BIBLIOGRAFÍA}

AA.VV., 1844 y ss.: Révue archéologique, París.

AA.VV., 1829-1885: Annali dell'Instituto di Corrispondenza Archeologica, Roma.

AA.VV., 1886 y ss.: Jahrbuch des deutschen archäologischen Instituts, Berlín.

AA.VV., 1886 y ss.: Mitteilungen des deutschen archäologischen Instituts in Rom, Roma.

AA.VV., 1898 y ss.: Jahreshefte des österreischen archäologischen Instituts, Viena.

ALLAG, Cl., 1985: "Une enseigne peinte à Saintes" Peinture murale en Gaule, Séminaires de I'AFPMA, BAR International, Series 240, 141-152.

ALLAG, Cl., 1998: "Vertault: la décoration murale", Bulletin Archéologique et Historique du Chantillonnais, ser. $6, n^{\circ}$ 1, 31-54.

BARBET, A., 1982: Les abords du Forum, Peintures murales trouvées dans les latrines et les boutiques près du forum de Bolsena, École française de Rome, Bolsena, t. VI, Roma.

BARBET, A., 1983: "La difusión du llle style pompéien en Gaule, 2a parte, Gallia, 41.1, 111-165.

BARBET, A., 1993: "Peintures murales en relation avec la fonction des pièces en Gaule. Bâtiments religieux, publics ou commerciaux, habitat privé", Functional and spatial analysis of wall painting (1992), BABesch, suppl, 9-17.

BASTET, F.L. y DE VOS, M.: 1979, Proposta per una classificazione del terzo stile pompeiano, Roma.

BELOT, E., 1985: "Architectures fictives de Famars. Mise en évidence d'une vogue picturale archaïsante antoninesévérienne", Revue du Nord, 67, 21-62.

BLÁZQUEZ MARTÍNEZ, J.M., 1993: Mosaicos romanos de España, Madrid

BLÁZQUEZ MARTÍNEZ, J.M. et alii., 1989: Mosaicos romanos de Lérida y Albacete, Corpus de Mosaicos de España, fasciculo VIII, Madrid.

BLOUET, G.A., 1828: Thermes de Caracalla, París

CAGNAT, R. y CHAPOT, V.,1920: Manuel d'archéologie romaine, t. II, París.

CAMARDO, D., FERRARA, A. y LONGOBARDI, N., 1989: Stabiae: le ville Castellamare di Stabia.

CARCOPINO, J., 1939: La vie quotidienne à Rome à l'apogée de l'Empire, Paris.

DE VOS, M., 1977: "Primo stile figurato e maturo quarto stile negli scariche provenienti delle macerie del terremoto del 62 d.C a Pompei", MededRom, 39, 29-47.

DE VOS, A. \& M., 1979: Die Wanddekorationen der Stabianer Thermen, Berlín.

DUMASY, F., 1983: "Scènes d'amphithéâtre et de cirque dans les peintures de la villa gallo-romaine du Liégeaud à La Croisille sur Briance (Haute-Vienne)", La peinture murale romaine dans les provinces de L'Empire, 199-219, Oxford.

DUMASY-MATHIEU, F., 1991: "La villa du Liégeaud et ses peintures. La Croisille-sur Briance (Haute-Vienne)", Documents d'Archéologie Française, 31, 192

FERNÁNDEZ CASTRO, M.C., 1982: Villas romanas en España, Madrid.

FERNÁNDEZ DÍAZ, A., 1999: La villa romana de Portmán: programa decorativo-ornamental y otros elementos para su estudio, Murcia.

FERNÁNDEZ DÍAZ, A., 2000: El programa pictórico de los edificios públicos y privados del área de Carthago Noua y su entorno, Tesis Doctoral defendida en la Universidad de Murcia.

FINATI, G.B. et alii., 1854-1857: Real Museo Borbónico, vols. I-XVI, Nápoles.
FRADIER, G., 1986: Mosaïques romaines de Tunisie, ed. Ceres Productions, Túnez.

GALLO, P., 1991: Terme e bagni in Pompei Antica, Pompeya. GARCIA ENTERO, V., 1997: "El conjunto termal de la llamada Villa del Camino Viejo de las Sepulturas (Balazote, Albacete)", Espacio, Tiempo y Forma, Serie, II, t. 10, 327-350.

GARCIA ENTERO, V., 2001: Los Balnea de las villae hispanorromanas. Provincia Tarraconense, en Monografias de Arquitectura Romana, 5, Serie Termas 1, Madrid.

GARDINER, E.N., 1967: Athletics of the ancient world, Oxford.

GAUCKLER, P. y HERLIN, A., 1910 y 1915: "Mosaïques de Tunisie", en Inventaire des Mosaïques de la Gaule et de l'Afrique, París.

GORGES, J.G., 1979: Les villas hispano-romaines Inventaire et problématique archéologiques, París.

GUIRAL PELEGRIN, C., 2000: "La decoración de los edificios termales", en Coloquio Internacional de Termas romanas en el Occidente del Imperio, Gijón (1999), 111-118.

GUSMAN, P., 1900: Pompéi, Paris.

HELBIG, W., 1868: Wandgemälde der vom Vesuv verschütteten Städte Campaniens, Lepzig.

KHANOUSSI, M., 1988: "Compte-rendu d'un spectacle de jeux athletiques et de pugilat sur une mosaïque de la région de Gafsa", Bull. Trav.Tun, 3, 33-54.

LAFAYE, P.G., 1909: "Mosaïques de la Narbonnaise et d'Aquitaine", en Inventaire des Mosaïques de la Gaule et de l'Afrique, París.

LE GLAY, M., 1983: "Hercule et la Juventus viennoise: à propos de la mosaïque des athlètes vainqueurs", Recueil d'Hommages à Henri Stern.

LEBLANC, O., 1995: "Le décor des Latrines des thermes des lutteurs à Saint-Romain-en-Gal (Rhône)", Actes des Séminaires de l'Association Française des Peintures Murales Antiques: 1990-1991-1993 (Aix-en-Provence, Narbonne et Chartres), Revue d'Archéologie de Picardie, 10, 239-263.

MAIURI, A., 1958: Ercolano. I nuovi scavi (1927-1958), Roma.

MIELSCH, H., 1975: "Römische Stuckreliefs", RM, Suppl. 21, Heidelberg.

MIELSCH, H., 1979: Die Stuckkaturen der Stabianer Thermen. Die Stabianer Thermen in Pompeji, ed. Eschebach, H. Berlín.

MILLIN, A.L., 1829: Description d'une mosaïque antique du Musée Pio-Clémentin, 1829.

MILLIN, A.L., 1811: Galerie mythologique, 2 vol. París.

ENNAÏFER, M., 1973: La civilisation tunisienne à travers la mosaïque, Túnez.

NIELSEN, I., 1990: Thermae et Balnea. The architectural and cultural history of roman public baths, Aarus.

NOGARA, B., 1910: I mosaici antichi nei Vaticano en el Laterano, Milán.

NOGUERA CELDRÁN, J.M., 1994: La escultura romana de la Provincia de Albacete, (Hispania Citerior-Conventus Carthaginensis), Estudios Albacetenses, serie I, Albacete. PICARD, Ch., 1959: La civilisation de l'Africa Romaine, París. RAMALLO, S. et alii., 2005: "La villa romana de la Quintilla (Lorca, Murcia). Análisis de su programa decorativo y ornamental", IX Colloque International de I'AIEMA, Roma, en prensa.

REBUFFAT, R., 1995: "Peinture et inscriptions", Actes des Séminaires de l'Association Française de Peintures Murales Antiques: 1990-1991-1993 (Aix-en-Provence, Narbonne et Chartres), Revue d'Archçéologie de Picardie, 10, 23-31.

REINACH, S., 1922: Répertoire de Peintures Grecques et Romaines, París. 
RODRIGO ZARZOSOSA, C. y JIMÉNEZ SALVADOR, J.L., 2004: "Documentos para el estudio de las excavaciones de Herculano, Pompeya y Estabia en el siglo XVIII bajo el patrocinio de Carlos III", en Bajo la cólera del Vesubio (Testimonios de Pompeya y Herculano en la época de Carlos III, Valencia, 14 de mayo - 12 de septiembre.

SABRIE, R. y M., 1995: Peintures romaines de Narbonne, Narbona.

SANTOS GALLEGO, S. de los, 1977a: "Excavaciones en la villa romana de Balazote (Albacete)", $N A H, 5,249-254$.

SANTOS GALLEGO, S. de los, 1977b: "Excavaciones en la villa romana de Balazote (Albacete)", en Symposium Arqueología romana, Barcelona, 367-370.

SANZ GAMO, R., 1987a: "Sistemas de calefacción de época romana en la provincia de Albacete", Información Cultura, 16, 3-14.

SANZ GAMO, R., 1987b: "Algunos materiales romanos utilizados en la construcción de las concamerationes", Oretum, III, 225-236.

SANZ GAMO, R., 1987c: "Notas sobre los mosaicos romanos de Balazote (Albacete)", Caesaraugusta, 64, 189-210.

SANZ GAMO, R., 1987d: "Mosaicos romanos del Camino
Viejo de Las Sepulturas (Balazote, Albacete), Al-Basit, 21, 43-64.

SANZ GAMO, R., 1989a: "Materiales cerámicos utilizados en la construcción de hypocaustos en el sureste peninsular: Clavijas y ladrillos recortados", CNA, XIX (Castellón, 1987), 877-883.

SANZ GAMO, R., 1989b: "Una villa romana bajoimperial en Balazote (Albacete)", I Congreso de Historia de CastillaLa Mancha, vol. IV, 243-249, Toledo.

SANZ GAMO, R., 1995: "El poblamiento rural del área de Balazote (Albacete) a la luz de las últimas investigaciones", en J.M. Noguera Celdrán (Coord.):El poblamiento rural romano en el Sureste de Hispania (Jumilla 1993), 339-356, Murcia.

SANZ GAMO, R. y ABASCAL PALAZÓN, J.M., 1993: "Novedades de epigrafía romana en la provincia de Albacete", Al-Basit, 19, 13-36.

SECCHI, G.P., 1843: /l mosaico dei atleti, Roma.

SOLIN, H., 1971: "I graffiti parietali di Roma e di Ostia", Acta of the 5th International Congress of Greck and Latin Epigraphy (Cambridge, 1967), 201-208. 